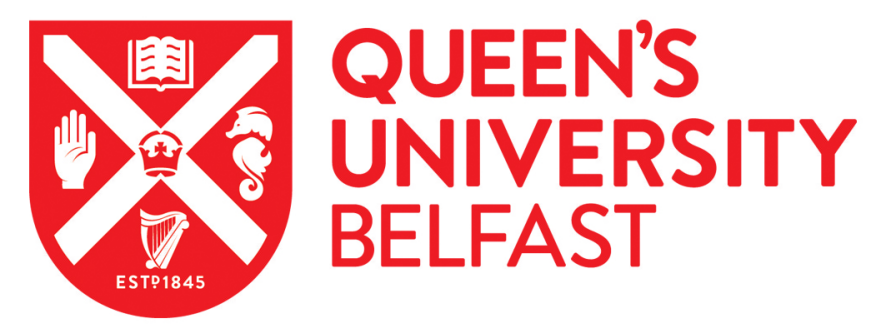

\title{
The financial economics of white precious metals - A survey
}

Vigne, S. A., Lucey, B. M., O'Connor, F. A., \& Yarovaya, L. (2017). The financial economics of white precious metals - A survey. International Review of Financial Analysis, 52, 292-308.

Published in:

International Review of Financial Analysis

Document Version:

Peer reviewed version

Queen's University Belfast - Research Portal:

Link to publication record in Queen's University Belfast Research Portal

Publisher rights

24 month embargo

Copyright 2017 Elsevier.

This manuscript is distributed under a Creative Commons Attribution-NonCommercial-NoDerivs License

(https://creativecommons.org/licenses/by-nc-nd/4.0/), which permits distribution and reproduction for non-commercial purposes, provided the author and source are cited.

\section{General rights}

Copyright for the publications made accessible via the Queen's University Belfast Research Portal is retained by the author(s) and / or other copyright owners and it is a condition of accessing these publications that users recognise and abide by the legal requirements associated with these rights.

\section{Take down policy}

The Research Portal is Queen's institutional repository that provides access to Queen's research output. Every effort has been made to ensure that content in the Research Portal does not infringe any person's rights, or applicable UK laws. If you discover content in the Research Portal that you believe breaches copyright or violates any law, please contact openaccess@qub.ac.uk. 


\title{
The Financial Economics of Silver, Platinum and Palladium - A Survey
}

\author{
Samuel A. Vigne ${ }^{\mathrm{a}}$, Brian M. Lucey ${ }^{\mathrm{b}}$, Fergal A. O'Connor ${ }^{\mathrm{c}}$, Larisa \\ Yarovaya $^{\mathrm{d}}$ \\ ${ }^{a}$ Queen's Management School, Queen's University Belfast, BT9 5EE, Northern Ireland, \\ United Kingdom and Trinity Business School, Trinity College Dublin, Dublin 2, Ireland \\ email: s.vigne@qub.ac.uk \\ ${ }^{b}$ Trinity Business School, Trinity College Dublin, Dublin 2, Ireland \\ email: blucey@tcd.ie (corresponding author) \\ ${ }^{c}$ The York Management School, University of York, YO10 5GD, England \\ email: fergal.oconnor@york.ac.uk \\ ${ }^{d}$ Lord Ashcroft Business School, Anglia Ruskin University, CM1 1SQ, United Kingdom \\ email: drlarisayarovaya@gmail.com
}

\begin{abstract}
This article provides a review of the academic literature on the financial economics of silver, platinum and palladium. The survey covers the findings on a wide variety of topics relation to the White Precious Metals including Market Efficiency, Forecastability, Behavioral Findings, Diversification Benefits, Volatility Drivers, Macroeconomic Determinants, and their relationships with other assets.
\end{abstract}

Keywords: Silver, Platinum, Palladium, Survey, Review

JEL Code E44; F33; G15; L72; Q31 
Contents

Page

1 Introduction $\quad 1$

2 Market Efficiency 2

3 Modeling Price Data $\quad 7$

$\begin{array}{llr}4 \text { Forecasting } & 10\end{array}$

5 Behavioural Aspects of White Precious Metals 12

6 Portfolio Diversification $\quad 14$

7 Volatility and White Precious Metals 21

8 The Macroeconomic Determinants of White Precious Metal $\begin{array}{ll}\text { Prices } & 28\end{array}$

9 The White Precious Metals and Other Assets 35

9.1 Gold . . . . . . . . . . . . . . . . . . . 35

9.2 Other Assets . . . . . . . . . . . . . . . . . . . 39

10 Silver Futures and Forwards 43

11 Exchange Traded Products and White Precious Metals 45

$\begin{array}{ll}12 \text { Conclusion } & 47\end{array}$ 


\section{Introduction}

This paper will survey the empirical and theoretical research that has been carried out to date on the the financial and economic aspects of the three white precious metals: Silver, Platinum and Palladium. A previous paper by O'Connor et al. (2015) provides a similar summary for gold and this paper aims to allow researchers to see the breath of research available on the remaining precious metals with ease.

Silver is one of the oldest financial assets with it's historical role as a currency to thank for this. The advantages of using precious metals as currency lied in their rarity, divisibility and lack of corrosion. A few currencies used base metals in history, such as Byzantium which use iron coins, but these proved to be too heavy and too easily rusted to be used as an effective currency Averbury (1903). Platinum and palladium were only added to the list of precious metals more recently. Platinum was originally seen as a nuisance by Spanish gold prospectors when panning for gold in the 16th century and palladium was only discovered in 1802 by scientists who where working on improved methods of refining platinum. While they are used as investment assets their primary source of demand is industrial such as their use in the production of catalytic converters for cars McDonald and Hunt (1982).

Though as investment vehicles the white metals are generally overshadowed by gold, there is still a significant volume of academic literature published on their economic role over the past few years (Figure 1. Interestingly, the increase in academic output on the white precious metals is in line with their increased role as investment vehicles, as it can be seen for silver in Figure $2^{1}$. The introduction of a silver ETF in April 2006 followed by platinum and palladium ETFs in 2010 heightened the attractiveness of white precious metals as investment assets by reducing the cost of investment significantly,

\footnotetext{
${ }^{1}$ Figures obtained from the annual GFMS World Silver Surveys.
} 


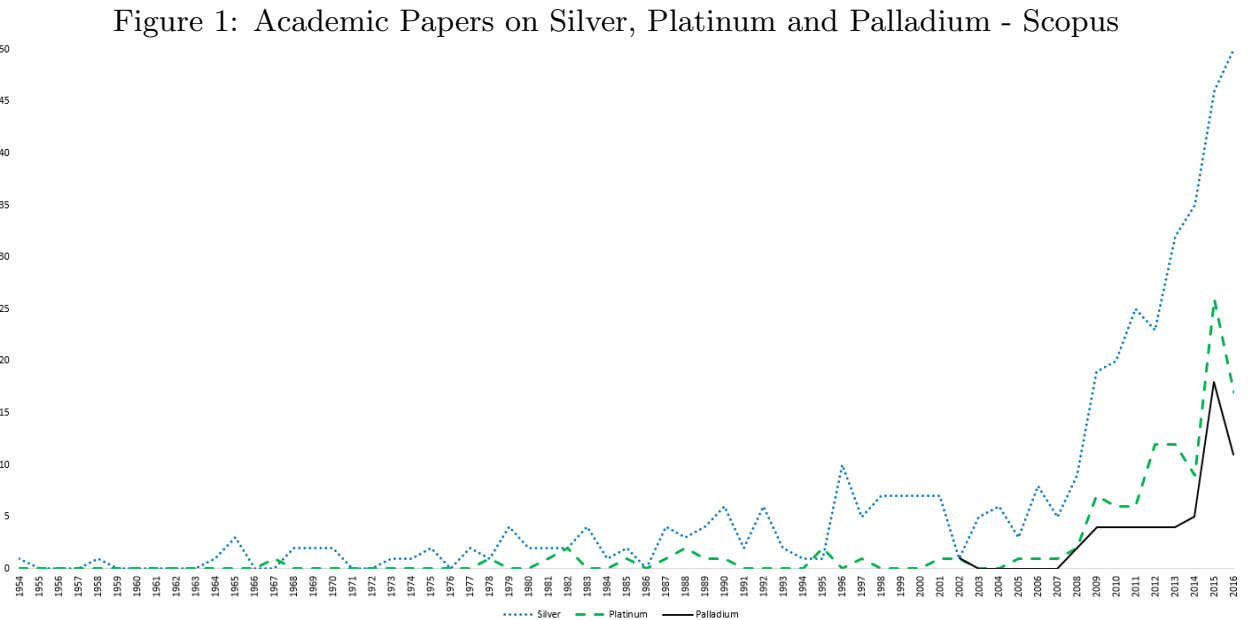

especially for smaller investors. New York is the more important market for silver, where the turnover is nearly about twice the size than the London market (Figure $3^{2}$, while platinum and palladium markets are based primarily in Zrich and the importance of London as a market place was growing in recent years Gold Field Mineral Services Ltd. (2015).

\section{Market Efficiency}

Silver markets have been traded 24 hours a day since at least the 1930's, with London, Bombay, Shanghai, San Francioso and New York all having active markets in 1932. Today's market is not too dissimilar with London, Shanghai, COMEX, the Multi Commodity Exchange of India and TOCOM in Japan being the major silver markets today. this points to a market which should be constantly involved in price discovery and adhere closely to the Efficient Markets Hypothesis, and there are plenty of studies addressing this question.

\footnotetext{
${ }^{2}$ Figures obtained from The Silver Institute (2016).
} 
800

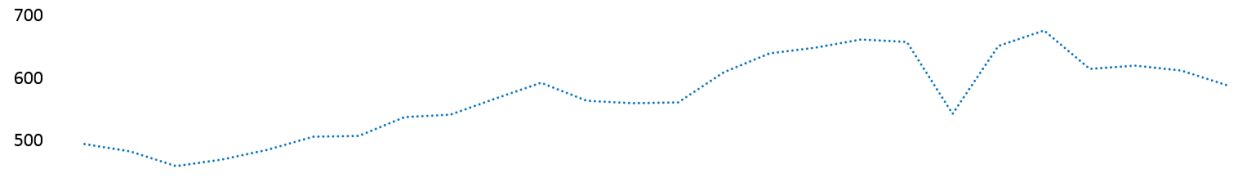

400

300

200

100
Figure 2: Global Demand for Silver by Type in Mio. Oz

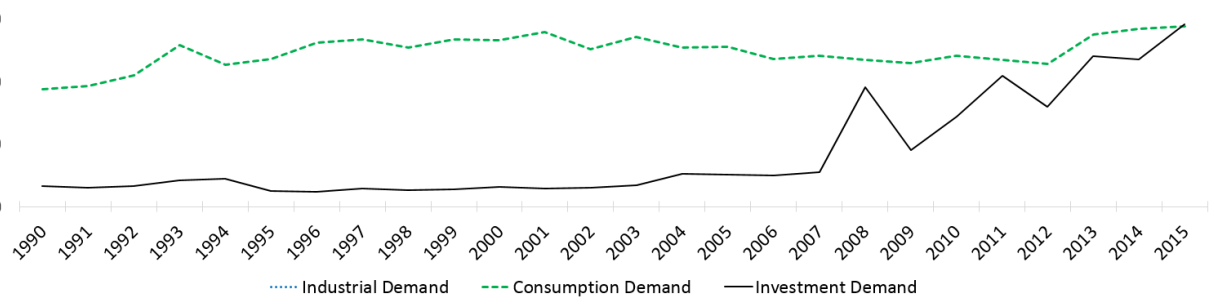

Figure 3: Annual Turnover of the COMEX and the LBMA in Mio. Oz

450

400

350

300

250

200

150

150

100

50

0
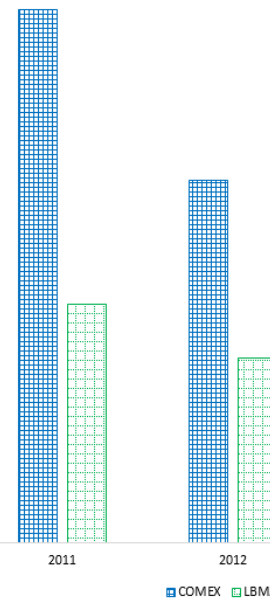

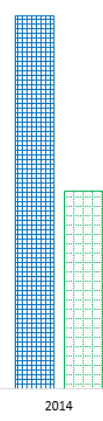

2014

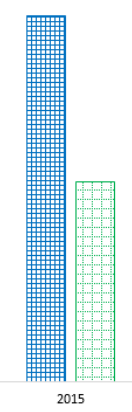


Solt and Swanson (1981) offers an early analysis on this question for silver up to the 1980's. The author finds strong evidence that silver prices are heteroscedastic, except for the logarithmic price series, where the mean of these price changes are nonzero, not stationary and not merely drifting. Serial dependence is also found but it is not significant enough to be profitably traded. These lead Solt and Swanson (1981) to the belief that silver markets are more speculative than a normal investment market.

Goss (1983) finds further evidence against the $\mathrm{EMH}$ in this time period with silver futures markets found not to be unbiased predictors of spot prices. But only very slight serial dependence in silver prices is found again indicating that it may not have been possible to profit from the inefficiencies found. Aggarwal and Sundararaghavan (1987) again test the efficiency of silver futures markets between 1980 and 1984 using a Markov chain model. Results point towards a change in behaviour of silver prices since 1981 due to the Hunt brothers attempt to corner the silver market. Considering the cycles found, traders could have earned excess returns, giving good evidence against weak-form inefficiency in the silver futures market between 1981 and 1983.

Varela (1999) examines the relationship between 15-, 30-, 45-, and 60day silver futures and their realised cash and delivery settle prices. The period considered ranges from 1971 to 1995. Silver series are found to be stationary in levels, making it impossible to predict cash prices with futures using cointegration and Error Correction Models (ECM). However, a simple regression model indicates that closest to delivery silver futures are a good predictor of the future cash price, showing efficient links between these markets.

Mutafoglu et al. (2012) question whether open futures positions can predict platinum and silver spot prices movements. Using the Commitment of Traders (COT) reports between 1993 and 2009 they use a VAR model with two variables: spot price returns and trader positions. Mutafoglu et al. 
(2012) use a generalised structural break test with unknown break points Andrews (1993) to test the stability of model parameters over the entire sample period. If structural breaks are detected the VAR analysis is repeated for each sub-sample period. Results from the entire sample show that white precious metal market returns explain trader's positions and that a major structural break happened in the early 2000's, after which the tendency of trader positions to follow returns became much stronger.

Frank and Stengos (1989) examined possible predictability of silvers rate of return. Results from daily, weekly and biweekly data between the mid 1970's and the mid 1980's for silver point to the possibility of an underlying martingale process, indicating that a nonlinear process generates observed silver returns and price of silver is an unpredictable stochastic variable.

Charles et al. (2015) brings this research up to date looking at daily spot prices for silver and platinum between 1977 and 2013. They test for weak-form efficiency using the automatic Portmanteau test Lobato et al. (2001) for the presence of conditional heteroscedasticity. They find that both markets fit the criterion of the adaptive market hypothesis Lo (2004), and that the markets have gradually become more efficient over the time period considered.

Batten et al. (2016) looks into possible silver price manipulation. Using 5 minute tick data between the $1^{\text {st }}$ of January 2010 and the $30^{\text {th }}$ of April 2015 the authors employ a cluster analysis procedure to try and detect price manipulation. Regarding silver, results point towards a large concentration of returns around the derivative expiry date, suggesting possible manipulation. Furthermore, a three component mixture model indicates abnormal market behaviour, which is also supported by a further method clustering the silver returns. However, Batten et al. (2016) warn the author in jumping to conclusions about possible manipulation of the silver market as the evidence provided is merely indicative and not a legal prove for foul play. 
Gil-Alana et al. (2015b) address the pricing structure of silver, platinum and palladium rely on a fractional integration modelling framework in order to identify structural breaks in the monthly data of the series between January 1972 and December 2012. Results indicate evidence of long memory processes for platinum, in contrary to silver and palladium where strong evidence for mean reversion is obtained. However, taking into account the respective structural breaks identified for the three white precious metals, all series seem to be non-stationary, so that exogenous shocks will affect the long memory behaviour of the series - hence advising policy makers to adopt measures in case white precious metals drift away from their original trend.

In another paper looking at long memory behaviour of the price of silver, Gil-Alana et al. (2015a) uses annual silver prices between 1792 and 2013 and finds that real silver prices are mean reverting; indicating that no long-run memory behaviour exists between silver and inflation rate. This indicates that exogenous shocks will affect real silver prices less intensely than gold prices.

Chatrath et al. (2001b) looks at structure of both gold and silver futures markets using daily prices of between 1975 and 1995. Firstly the authors test for a correlation dimension then build on this correlation integral to test the price series for nonlinearity and deterministic chaos. Finally, a Kolmogorov entropy measures the degree at which the time series movements are predictable. Results reveal that the silver series has nonlinear dependencies, but that these are not consistent with chaos, therefore allowing for a certain degree of predictability.

Fassas (2012) argues that the price increase in precious metals between May 2007 and February 2011 was partly due to the flow of precious metals into Exchange-Traded Products (ETPs). Looking at 28 precious metal ETPs and the weekly spot returns of silver this aper finds a significant correlation between silver returns and the flows into silver Exchange-Traded Products exists. However granger causality tests indicate that there is no 
causal relationship between the two, while ETP flows are a driving factor for platinum and palladium prices.

Roberts (2009) looks at longer term returns for silver and platinum using monthly data from 1947 to 2007 and rather than simple randomness cyclical phases in the prices are found to exist. A Bry and Boschan (1971) procedure is used to identifies turning points in time series by adjusting for outliers to create a smoothed time series. This indicates that silver prices are not best characterised by a random walk.

Figuerola-Ferretti and McCrorie (2016) base their research on the explosive/multiple bubble technology developed by Phillips et al. (2015) to analyse the effect of the Global Financial Crisis on the price behaviour of gold, silver, platinum and palladium by looking at weekly data between 2000 and 2013. Evidence points towards short periods of mildly explosive behaviour in the prices of all precious metals, furthermore, while the Global Financial Crisis led the gold price to deviate from fundamentals, it seems that silver and palladium were rather affected by the launch of ETFs rather than the financial crisis as such.

Working with 12,187 daily observations of the price of silver between January 1968 and March 2016, alongside 6,561 daily observations of the prices of platinum and palladium between April 1990 and March 2016, Almudhaf and AlKulaib (2016) underline the importance of outliers for white precious metal prices by identifying that a traditional buy-and-hold strategy outperforms an attempted market timing strategy. Indeed, Almudhaf and AlKulaib (2016) show that large price increases of precious metals tend to be pooled around single days and that missing these individuals days would come at high cost for an investor, who should rather follow a more long-term classical investment strategy.

\section{Modeling Price Data}

Nadarajah et al. (2015) test which GARCH specification performs better 
when modeling the returns of different commodities, including silver. Using daily price returns from the March 1993 to March 2013, finding that the best fitting model for silver price returns is the Skewed Exponential Power (SEP) distribution, in line with Cheng and Hung (2011).

Another approach is to use an asymmetric GARCH (AGARCH) model Cochran et al. (2016) with a conditional skewed generalised $t$ (SGT) distribution. Similar to Demiralay and Ulusoy (2014) the authors study the performance of VaR measures obtained from this model to results from an AGARCH model with a normal and student $t$ distribution. For silver, an AGARCH model with the SGT distribution offers the best fit. Further findings point towards time-variation in the skewness for silver, as well as in the peakedness and tail thickness parameters of silver returns. Results from a Wald test Engle (1984) implies that higher order moments of silver returns, like skewness and kurtosis, are time-varying. An important difference between this paper, and Demiralay and Ulusoy (2014) and Nadarajah et al. (2015), is the much shorter period of time used by Cochran et al. (2016): daily spot returns of silver from 1999 to 2010.

Demiralay and Ulusoy (2014) addresses how best to model value-at-risk (VaR) for silver, platinum and palladium. Working with daily data January 1993 and 2013, the author fits the data into three different non-linear long memory volatility models (FIGARCH, FIAPARCH, HYGARCH) and finds that for all three white metals, a Fractionally Integrated Asymmetric Power ARCH (FIAPARCH) model is best suited to capture their long memory, asymmetry and fat tails, outperforming the other models in predicting oneday-ahead VaR positions.

Degiannakis and Potamia (2016) base their research on the recommendations of the Basel Committee on Banking Supervision and examine whether inter-day or intra-day model provide accurate predictions for reliable Valueat-Risk (VaR) and Expected Shortfall (ES) forecasts. Daily data for silver between the $3^{\text {rd }}$ of January 2000 and the $5^{\text {th }}$ of August 2015, indicates that a 
GARCH-skT model, relying on inter-day data, provides better results than a HAR-RV-skT model, as it satisifes most of the conditions implied in VaR and ES forecasting, but that it overall fails to provide accurate forecasts of the risk measures implied.

Recently, Zhang and Zhang (2016) examined the Value-at-Risk (VaR) and statistical properties in the daily price returns of gold, silver, platinum and palladium between the $11^{\text {th }}$ of January 2000 and September 2016. A complex two stage methodology relying on different GARCH models reveal that gold has the highest and most steady VaR values of the group while palladium has the most volatile and lowest VaR values of all four precious metals. Further results indicate that the VaR values of silver are more volatile than those of platinum, while the residuals of both metals are characterised by heavy-tail distributions. Auer (2015) also found that there was significant evidence of time-variation for both the skewness and the kurtosis of white precious metal returns.

Caporin et al. (2015) focuses on the behaviour of silver, platinum and palladium spot prices return, volatility and liquidity. A first major contribution to the field is the data used in the paper: trading quotes issued by the Electronic Brokerage Services (EBS) and provided by ICAP plc. The time frame observed ranges from December 2008 to November 2010, where $100,962,954$ quotes were observed for silver, amounting to 27,638 trades and a volume of $1,173,425,000 \mathrm{oz}$ of silver traded. Results from modeling the returns and volatility of the time series indicate the presence of a stochastic periodic behaviour and the possible presence of long-range dependence in the volume time series. In response to these features, Caporin et al. (2015) work with a multi-factor Generalised Autoregressive Moving Average (GARMA) model as proposed by Woodward et al. (1998) which allows for long-memory behaviour associated with specific periodic frequencies. The silver volume GARMA modeling approach of Caporin et al. (2015) can be used to forecast both volume levels and volume density if upgraded with a GARCH or 
EGARCH equation. The authors conclude their work by saying that white precious metals have features comparable to those of more traditional assets and that market liquidity of silver, platinum and palladium is characterized by intra-day seasonalities and very strong commonality. More specifically, platinum is found to be the least liquid and least volatile metal of the precious metals considered.Morales and Andreosso-O'Callaghan (2011), using data between 1995 and 2010, found that the standard deviation of daily silver returns is more than twice the standard deviation of gold and if the precious metals only palladium has a higher standard deviation than silver.

\section{Forecasting}

A large number of papers have addressed the question of whether it is possible to forecast future prices of the white precious metals. An early study by Lashgari (1992) uses daily, weekly and monthly silver prices running from 1970 to 1989 in order to obtain optimal silver price forecasts using an exponential smoothing time series model. Using daily silver prices offers better results than weekly or monthly prices, but no trading profits could be realized.

Escribano and Granger (1998) use a battery of testing procedures, finding that non-linear forecasting models for silver perform better than random walk processes; however, this is only the case for in-sample analyses, as the predictive power vanishes for the out-of-sample period. Considering the futures market of precious metals, Narayan et al. (2013) look at whether daily futures prices of gold, silver, platinum and oil predict the spot prices of their respective market. The window considered is the longest for gold and silver, ranging from 1980 to 2011, while it is somewhat shorter for platinum, starting in 1983. Results of linear and non-linear models show that futures returns only predict spot returns in the case of silver but not in the case of platinum, leading to a potential of profit realisation in the case of silver, but not in the case of platinum. However, time-variation results indicate that 
the profit potential was lowest during the Global Financial Crisis.

Urquhart (2016) analyses return predictability for gold, silver and platinum by fitting daily data between the $5^{\text {th }}$ of January 1987 and the $30^{\text {th }}$ of September 2014 into a battery of tests. Results indicate time-variation in the predictability potential of silver and platinum returns, where a jointrank test indicates that silver returns could only have been predicted with confidence until April 1999, while the time frame is longer for platinum prices, which could have been predicted until March 2001. However, results are inconclusive when considering different testing procedures, leading Urquhart (2016) to work with a rolling window approach highlighting the best prediction potential for platinum and the worst prediction potential for silver.

Pierdzioch et al. (2016a) discusess the statistical and economic performance of different forecasting models in regard to the choice of the Information Criteria selected to determine the boosting algorithm. Using monthly data from January 1987 to September 2014 and using a large set of predictors to forecast the excess return of silver to 1-month LIBOR. The authors develop a trading algorithm in which an investor should buy silver if the forecasted excess return is above the historical real-time mean of excess returns. In such a scenario, the trading rule performs better under the Akaike Information Criterion (AIC) then under the Minimum Descriptive Length (MDL) proposed by Bühlmann and Hothorn (2007). Even though the forecasting model for silver performs well, Pierdzioch et al. (2016a) warn the readers that the outlined model might not survive an economic performance evaluation.

Fritsche et al. (2013) consider silver price forecasts obtained from Consensus Economics Inc. for different forecast horizons between 1995 and 2012 and rely on the market-timing approach proposed by Pesaran and Timmermann $(1992,1994)$ in order to test for the accuracy of silver price forecasts. Results for silver are different than those obtained for gold; indeed, it is 
proven that silver price survey forecasts contain information on the subsequent price changes, in contrast to gold where forecasts are not accurate in predicting future price movements.

\section{Behavioural Aspects of White Precious Metals}

Yang and Brorsen (1993) focuses on futures prices arguing that past models have failed to successfully explain non-normality and dependence in speculative price changes. The authors apply a GARCH model and deterministic chaos processes to daily closing futures prices of silver, platinum and palladium between January 1979 and December 1988 in order to detect market anomalies. Building upon a GARCH model that generates data with fatter tails, their methodology (proposed by Yang and Brorsen (1993) captures day-of-the-week effects, seasonality in variance and maturity effects Milonas (1986) of silver futures prices. The GARCH model is augmented with a Residual Test in order to limit forecasting errors Brock et al. (1996). Test results indicate a strong calendar-day effect for silver since the variance of silver futures prices is larger on certain days of the week and after holidays. Concerning platinum and palladium, a calendar-day effect on the variance is observed on Tuesday and after holidays; Monday is only found to be significant for palladium. Further results point towards seasonality in the variance.

Lucey and Tully (2006a) study seasonality in daily COMEX silver cash and futures contracts between 1982 and 2002 by testing the unconditional and conditional means and variances of silver cash and futures prices. They tests for seasonality in the unconditional variance Levene (1960) whlie controlling for heteroscedasticity and autocorrelation White (1980) and . Results from an LGARCH model point to an increased variance on Mondays for silver cash prices in line with Yang and Brorsen (1993), and a lower variance on Wednesdays for futures. Lucey and Tully (2006a) then augment the GARCH framework by including day-of-the-week dummy variables in 
both the mean and the variance and find that the seasonality in silver price returns is not due to daily variation in risk. Naylor et al. (2014) and Baur (2013) find a monthly February effect in both silver prices and silver ETFs.

Auer (2015) finds no Friday the $13^{\text {th }}$ effect for silver returns. The author builds upon the findings of Kolb and Rodriguez (1987) and works with a dummy-augmented GARCH model to understand the impact that certain days have on the conditional means of silver returns. The methodology used is slightly different from Lucey and Tully (2006a) and relies upon a GARCH model with time-varying Skewness and Kurtosis (GARCHSK) Auer (2015) adds lagged returns to the mean equation in order to capture potential serial correlation and by adding two dummy variables in the mean equation according to calender-days of interest.

Lucey (2010) finds evidence for the existence of a lunar cycle on precious metal returns. Considering daily fixing prices for silver traded in London between January 1998 and September 2007 against lunar phases, Lucey (2010) applies a battery of classical descriptive and analytic tests and finds that returns around the full moon tend to be negative in contrast to positive returns around the new moon. The existence of lunar seasonality for silver is in line with previous findings from Dichev and Janes (2003) and Yuan et al. (2006) who did similar work on stock market returns. On the other hand, the evidence for a lunar cycle on the return of platinum prices is very weak.

Recently, Lucey and O'Connor (2016) identified whether or not investors in the gold and silver markets are affected by psychological barriers in regard to prices ending in 0 and in 00 . Intraday silver prices between the $2^{\text {nd }}$ of March 1975 and the $30^{\text {st }}$ of April 2015 are taken into account and tested for the uniformity of their distribution. While evidence is found for the existence of psychological barriers in the price of gold, no such evidence is observed for silver, who's price seems unaffected by the format.

Working with the exact same data set as Fritsche et al. (2013) mentioned 
above Pierdzioch et al. (2013) model the behaviour of the authors of gold and silver price forecasts and find evidence for irrational behaviour on both markets. More specifically, results based on the asymmetric loss function proposed by Elliott et al. (2005) to test for the rationality of forecasts, indicate a herding behaviour of some forecasters, while others tend to issue more extreme forecasts in order to differentiate themselves from others. The authors suggest that this change in behaviour tends to occur depending on the customers of silver price forecasts, resulting in biased forecasts in order to assure a loyalty of the main group of customers.

\section{Portfolio Diversification}

The diversification benefits of holding gold in a portfolio of assets is well documented, see O'Connor et al. (2015) for a review. As the white metals are also classed as precious it would then seem to follow that they would be useful in portfolio construction. However all three are heavily used as industrial metals, in contrast to gold which should have little or no correlation with general economic activity as it is overwhelmingly used for investment. Jaffe (1989)is one of the first papers to address the issue empirically for silver using data from 1971 to 1987. Silver was found to have a high correlation with gold (0.744) and with Toronto Stock Exchange (TSE) gold stocks (0.589). However with common stocks a very low correlation of 0.134 showing its usefulness in a diversified portfolio.

Looking again at risk premium in the silver futures market, Kocagil and Topyan (1997) analyse the possible relationship between the risk premium, futures trading and the $\mathrm{S} \& \mathrm{P} 500$. A theoretical model is used to illustrate the equilibrium relationship between cash and futures prices and fitted with daily data between 1990 and 1994. Evidence uncovers a positive relationship between risk premium and daily futures trading and to a negative relationship with the S\&P 500, pointing towards silver's role as an portfolio hedge.

McCown and Zimmerman (2007) looks into the investment performance 
of the metal by using multiple asset pricing models. The data used is the monthly spot price of silver and the US CPI between over a 36 year period to 2006. When looking at investment performance, they estimate the Capital Asset Pricing Model (CAPM) for silver. using 3 three different proxies for the market portfolio: the MSCI World Index, the MSCI World Index denominated in US Dollars and the MSCI World Index denominated in local currencies. The results for silver are independent of the index used as market portfolio proxy; small Betas (around 0.33) are recorded for a period of up to six months and they become negative after one year. The findings suggest that silver is a less volatile investment than the market in the shortrun, and that it moves in opposite direction than the market on the long-run - arguments in support of silver's ability to be used as a hedging tool against stock markets.

Erb and Harvey (2006) uses data between December 1982 and May 2004 and shows that silver has very low correlation with other major commodities, except gold (0.66) and has had constant negative excess, spot, and roll returns. To assess silvers hedging ability against sovereign debt they apply a liability hedging technique proposed by Sharpe and Tint (1990). Silver is show to act as a hedge for Treasury Inflation Protected Securities (TIPS) and 10 Year Treasury Bonds between 1997 and 2004, but not for long term US debt between 1982 and 2004.

Investing in Miners is seen as an alternative and cheap route to get exposure to precious metals ina portfolio. Conover et al. (2009) uses daily returns for silver and platinum between the 1973 and 2006, as well as the equity performance of precious metal miners. An investment into the equity of precious metal miners proves to be much more efficient than a direct commodity investment; a $25 \%$ miner allocation in a portfolio of US equities leads to an increase in returns and a decrease in portfolio standard deviation. In addition gold is found to be a superior investment relative white precious metals, results in line with Hillier et al. (2006). Also, the investment benefits 
held by precious metals varied over time and grew during the later years of the sample. Adding silver to a portfolio is found to be of greater benefit when the Fed policy is restrictive rather than expansive, findings somewhat in line with Conover et al. (2008) who advised investors to use monetary conditions as a guideline for portfolio allocation; however, Conover et al. (2009) points out the impossibility of knowing that return patters are caused by monetary policies or some other variable.

Using monthly data from 1995 and 2010 Belousova and Dorfleitner (2012) look at the impact of adding silver to a diversified portfolio of stocks, sovereign bond and the money market instruments during bull and bear markets. Adding silver or platinum to a portfolio during bull markets reduces volatility and enhances return. During bear markets silver only reduces portfolio risk, in line with Hillier et al. (2006), but platinum loses its diversifying ability.

Bruno and Chincarini (2010) generatings optimal mean-variance portfolios for more than 15 different countries between 1930 and 2009 but the only national portfolios explicitly advised to have holdings in silver where the cases of Germany, Mexico and the United States of America between 1970 and 2009. For both Germany and the US., an optimal allocation of $0.01 \%$ to silver is advised which is much lower than for gold, whereas Mexico stands out with a much higher proportion of $1.98 \%$ of silver.

Hammoudeh et al. (2013) focuses on the daily downside risk associated with gold, silver, platinum, palladium, oil and the S\&P 500 Index between 1995 and 2011 within a VaR framework, a period of primarily rising precious metals prices. The VaR metrics are computed at the $99 \%$ confidence level and two Asymmetric Power Autoregressive Conditional Heteroscedasticity (APARCH) models are used to forecast results, where one follows a normal student- $t$ distribution and the second a skewed- $t$ distribution. Hammoudeh et al. (2013) constructs three optimal portfolios: (1) consisting only of the four precious metals, (2) consisting of all six assets under study, and (3) 
consisting of gold, oil and the S\&P 500. Portfolio 1 has the highest annual return, around $9 \%$, but also a higher standard deviation than 2, containing the greatest amount of different assets, which scored an average yearly return of $8.625 \%$. Looking at portfolio efficiency, the authors conclude that an optimal portfolio should hold a higher proportion of gold than any other asset (even though silver was the best performing asset over the time frame observed), and that overall, the pure precious metal portfolio proved to be the least efficient.

Hillier et al. (2006) looked at silver returns in the Zurich market and the London platinum price against the S\&P 500, the MSCI Europe, the MSCI Australia and the MSCI Far East Index between January 1976 and 2004 and apply a GARCH $(1,1)$ model. During this period silver had about twice the standard deviation of the S\&P 500, while platinum gave the highest mean daily returns. Subsample analyses indicate a constant very small correlation with the S\&P 500 of an order between -0.05 and 0.05. Looking into the diversifying properties of an investment in white precious metals, the persistent negative elasticity of silver and platinum indicates that it was a valuable diversifying asset against an S\&P 500 portfolio but not so in regard to the MSCI indices. Focusing on periods of high volatility and poor returns of stock markets, silver's hedging abilities were found to be to be stronger than those of platinum. However, when looking at what metals to optimally hold in a portfolio, silver did not perform as well as both gold and platinum which scored higher returns over the period.

Li and Lucey (2017) looks at the safe haven characteristics of the white metals and gold across 11 countries from 1994 to 2016. All the precious metals are found to be safe havens at different times during the sample and silver is found to out perform even gold in relation to US equities with platinum second best. But no precious metal is consistently a safe haven. The paper goes on to examine if there are determinants that can explain when a metal will act as a haven. Economic policy uncertainty is the only 
variable found to consistently determine whether a metal acts as a safe haven across markets.

Sarafrazi et al. (2014) focus on daily downside risk of euro-zone national equity and sovereign bond markets by classifying the countries in two distinct groups: the PIIGS (Portugal, Italy, Ireland, Greece and Spain) and the Core (Germany, France, Austria, The Netherlands and Finland). The period observed ranges from March 1999 to November 2012. Using the Sharpe ratio the optimal portfolio over the full period is composed of a surprisingly large share of commodities with $13 \%$ gold, $11 \%$ copper, $11 \%$ oil, $9 \%$ silver and $7 \%$ platinum. When looking the subperiod between July 2007 and November 2012, results show that from all the commodities observed, only gold and silver prove to contribute to diversification benefits to stock and bond portfolios by increasing the sharpe ratio.

Agyei-Ampomah et al. (2014) used data from 1993 to 2012 silver returns were on average negatively correlated with bond returns; the hedging ability is particularly strong for Austria,n Belgian, German, Italian, Portuguese and UK bonds. Platinum's hedging ability is even stronger while palladium's is much weaker. In sub period analysis silver was only an effective bond hedge between 1993 and 2000, platinum was effective over that time as well as 2007 to 2012.

Chang et al. (1990) tests the theory of normal backwardation by applying the CAPM model to investgate whether silver futures between January 1964 and December 1983 carried systematic risk and if this risk was rewarded. The Dow Jones Cash Commodity Index is used as a proxy for the market portfolio and the risk-free rate used is the end-of-period return on onemonth Treasury-bills. Results show that investing in silver futures yielded higher returns than investing in futures contracts of other metals, but was also linked to higher volatility. Furthermore, silver outperformed the stock market over the period observed and has a $\beta$ close to 1 (later supported by Cochran et al. (2012), on the other hand, the $\beta$ of platinum was of 0.848 
for the same period. Chang et al. (1990) conclude by finding that based on standard deviations of returns, silver and platinum futures are riskier than common stocks but earn less return per risk unit than equity - therefore strongly challenging the attractiveness of white precious metals futures as an investment asset.

In a recent paper, Mensi et al. (2015) look at the linkages between silver and other commodities and develop implications for Saudi-Arabian investors derived from daily data between 2005 and 2013. They allow for asymmetric volatility responses to both positive and negative shocks, and long memory in the volatility dependence. Results from initial tests point towards a negative linear correlation between silver and Saudi Arabian stock returns - a finding overturned using a DCC-FIAPARCH model which showed evidence for timevarying conditional correlations between both series, disproving the capacity of silver to be used as a hedge or a safe haven against the Tadawul.

More recently, Reboredo and Uddin (2016) work with a quantile regression approach and analyse the impact of financial stress and policy uncertainty on weekly gold, silver platinum and palladium futures prices between 1994 and 2015. Results find no Granger causality between the prices of commodity futures and financial uncertainty, but that financial stress has a positive effect on gold and silver prices, in contrary to platinum and palladium.

Whether the four main precious metals acted as a safe haven against the S\&P 500 and US 10 year bonds between January 1989 and July 2013 is addressed by Lucey and $\mathrm{Li}$ (2015). The methodology is upgraded with the approach of Ciner et al. (2013) to identify time-variation in the safehaven property of silver, platinum and palladium and graphically depict it. Results for silver have interesting implications for investors; concerning equity, silver was only a safe haven during the last quarter of 2009 and the first quarter of 2010, the performance of gold, platinum and palladium was much better and it had safe haven properties during more quarters - 
concerning bonds though, silver was a safe haven at times during which gold failed to be, but also during far more quarters than both platinum and palladium. Empirically however, gold should be considered the better safe haven investment for it acts as one more often than white precious metals.

Bredin et al. (2017) continue the investigation into the equity hedging abilities of silver and platinum by considering daily, weekly and monthly price returns between 1980 and 2014. The hedging potential is identified via a Value-at-Risk ( $\mathrm{VaR}$ ) procedure detecting the level of tail- and downside risk associated with silver and platinum investments, and measures the respective cost or benefit of such investments by considering risk-adjusted returns against an S\&P 500 portfolio. Results indicate the superiority of gold to act as a hedge, while the equity risk reduction potential of silver and platinum only seems to be strong on a short time horizon but not on long time horizons.

Pierdzioch et al. (2016b) consider the ability of daily gold, silver, platinum and palladium prices between 1999 and 2015 to act as a hedge against exchange rate movements from the US Dollar,o the Yen, the Canadian Dollar, the Euro, the Pound Sterling and the Australian Dollar. Results indicate that silver is the overall better exchange rate hedge than platinum and palladium. Silver is found to be an asymmetric hedge against exchange rates: it is a weak hedge in times of US Dollar appreciation, but a strong hedge, even a safe haven, during times of US Dollar depreciation. Platinum and palladium are not very effective currency hedgers except for their pronounced ability to hedge depreciation of the US Dollar against the Canadian and the Australian Dollar. An earlier study by Jaffe (1989) found that correlation coefficient is that between silver and the German Mark/US Dollar exchange rate was -0.252 , the lowest of the assets addressed. 


\section{Volatility and White Precious Metals}

The relatively high volatility of precious metals prices is other other side of their ability to diversify portfolio risk and act as safe havens. Silvers history includes the Hunt brothers cornering of the market in 1981 and the resultant crash in prices (the role of the Hunt family on the silver market can be found in Fay (1982) among others). Here we will look at the economic drivers of the white metals volatility.

Barnhill and Powell (1981) address which determinants caused the unusually high volatility of the silver price between July 1979 and April 1980 by looking into the demand and supply for silver, as well as into the relationship between the price of silver and macroeconomic indicators. This points towards multiple explanations for the sharp increase of the silver price in late 1979. First was a considerable shortfall of silver production relative to the commercial demand for silver, leading to the belief that silver was undervalued. Secondly the large acquisition of silver by the Hunts. Also rising investment demand for silver due to unattractive real returns offered by conventional investments and political actions undertaken by the government of India and the United States of America restricting both access and reallocation of a large portion of above-ground silver stocks was also highlighted. The collapse of the silver price in early 1980 is explained by a fall in industrial U.S. commercial demand by $40 \%$, accompanied by a slow-down of cash silver acquisition by the Hunt family. On the supply side, an increase of $200 \%$ in scrap supply as well as an increase of $80 \%$ in recycled silver resulted from the unusually high prices. Finally, a growing attractiveness of alternative investments mixed with a negative investor sentiment against silver led to a very heavy drop of the price in late March 1980.

Hammoudeh and Yuan (2008) finds that Silver's volatility, between 1990 and 2004, is more persistent that the volatility of industrial metals such as copper. Silver is found to have a low sensitivity to bad news in the short run, giving it safe haven like qualities. Increases in interest rates reduce silver 
price volatility. Oil price shocks have the effect of cooling precious metals volatility, making them good diversifiers in a commodity portfolio. Nowman and Wang (2001) look at the monthly price of silver between February 1970 and May 1997 with nine models designed to analyse the volatility of silver. Results show that price volatility depends strongly on the price level of silver itself, possibly driven by the 1981 peak in the silver price.

Using annual prices between 1900 and 2007 obtained from the US Geological Survey (USGS) Chen (2010) looks at precious metals in order to gain a longer run view of the price volatility of precious vs. industrial metals. The results indicate much higher volatility figures for industrial metals. Looking at within- and between-group volatility shows that volatility transmission is higher within the metal groups than between the metal groups; in other words. In a final step, Chen (2010) applies a single factor asset pricing model and finds that the importance of global macroeconomic factors in explaining silver and platinum price volatility has increased over the time period observed. Between 1900 and 1971 over $90 \%$ of the price volatility of silver can be attributed to commodity-specific risk against under $10 \%$ to be attributed to global macroeconomic risk factors; between 1972 and 2007, these numbers shifted and the global macroeconomic risk share is above $36 \%$ against nearly $62 \%$ for commodity-specific risk factors. A similar picture is observed for platinum, where the share of commodity-specific risk between 1900 and 1971 is of more than 93\% against around 87\% between 1972 and 2007.

Using a GARCH $(1,1$,$) model Vivian and Wohar (2012) finds further$ evidence of high volatility persistence of the silver, platinum and palladium prices. Focusing on interactions between precious metals, Morales and Andreosso-O'Callaghan (2011) investigate the nature of volatility spillovers amongst daily precious metal returns between 1995 to 2010 using GARCH and an EGARCH models. Over the entire period volatility runs from gold to silver but not the other way around. Morales and Andreosso-O'Callaghan 
(2014) examine volatility persistence between precious metal returns and equity indexes up until the global financial crisis of 2008 by looking at daily silver and platinum returns from 1995. GARCH and EGARCH results point toward an insignificant relationship between the white metals and the Dow Jones index, but to a significant positive relationship with both the FTSE100 and the Nikkei225. A significant positive relationship between the volatility of silver and Brent crude oil is also found.

Sari et al. (2010) look at volatility transmission between the four precious metals from 1999 and the $19^{\text {th }}$ of October 2007. Impulse response functions show that over the long run gold accounts for $16 \%$ of silvers variance; in line with Lucey and Tully (2006b). Interestingly silver is found to explain $23 \%$ of gold price volatility. In the short-run, unexpected shocks to gold, platinum and palladium prices have a positive and significant impact on the price of silver and vice versa. Silver explains about $10 \%$ of the variations of both platinum and palladium prices, while platinum and palladium explain about $22 \%$ of their respective price fluctuations.

Using a longer sample from 1987 to 2012 Balcilar et al. (2015) dispute Sari et al. (2010). Using a Bayesian Markov-Switching Vector Error Correction Results it is shown that during high volatility regimes, the impact of change of the gold price on silver is about $1.25 \%$; against an impact of about $0.07 \%$ from silver on gold. The impact of change of the gold price on both platinum and palladium is of about $0.8 \%$, while the impact of change of silver prices is practically non-existent for both platinum and palladium prices.

Looking at weekly closing spot prices between 1990 and 2006, Choi and Hammoudeh (2010) assess issues of volatility and correlation in relation to financial and geopolitical crises. They distinguish between high- and lowvariance regimes using a Markov-switching model. Low volatility regimes for silver last about 50 weeks against about 25 weeks for high volatility regimes. Though silver is generally highly volatile around the same periods as gold, 
in the early 2000's silver volatility was significantly lower. Using a DCC multivariate GARCH model show that gold and silver's correlation is fairly high and remains pretty constant through time.

Arouri et al. (2012) analyse the returns and volatility of gold, silver, platinum and palladium in order to investigate both long memory properties and the potential of structural changes of the price series between 1999 and 2011 using squared daily returns as a measure of volatility. Results from an ARFIMA-FIGARCH model finds no long memory evidence for spot silver prices. They find only three structural breaks for silver spot and futures prices; these breaks found are not in line with Vivian and Wohar (2012), but the spot price breaks in 2001 and 2004 are observed by Morales and Andreosso-O'Callaghan (2014). Platinum futures returns are found to exhibit the highest long memory property in the variance equation, suggesting that platinum might not be able to function as a good hedging instrument; long memory patterns are also observed for palladium futures prices.

Cochran et al. (2012) also work with a FIGARCH model to examine the return and long memory properties of daily return volatility for copper, gold, platinum and silver between 1999 and 2009. The silver return series is modeled as a multi-index CAPM proposed by Chang et al. (1990). Results point towards a negative effect of interest rates movement on silver but not on platinum (results in line with Jaffe (1989) and Hammoudeh and Yuan (2008) and a negative relationship between exchange rates and both silver and platinum returns, proving that the law of one price holds for silver. FIGARCH results show evidence of long memory characteristics for the two white precious metals, while the metals return volatility share a positive relation with changes in the VIX. Dummy variables indicate an increase in volatility of the prices of the three precious metals since the Global Financial Crisis. USing daily data over a much shorter period (20092014) Bunnag (2015) examine the same issue. Results point towards a short run persistence of shocks on the dynamic conditional correlation for gold 
with silver, and towards an important long run persistence of shocks on the dynamic conditional correlation for palladium with silver.

Sensoy (2013) contrasts the findings of Cochran et al. (2012) and finds that the Global Financial Crisis of 2008 has no effect on volatility levels of silver, but indeed caused an upwards shift in the volatility levels of platinum and palladium. The data taken into account are the daily gold, silver, platinum and palladium spot prices between 1999 and 2013 filtered through an $\operatorname{ARMA}(\mathrm{p}, \mathrm{q})$ process. The results show that while 2008 had no effect on volatility levels of silver, but silver is found to have a volatility shift contagion effect on platinum and palladium. On the other hand, it is found that platinum and palladium have no volatility shift contagion effect on one another. Sensoy (2013) argues that platinum and palladium were historically not considered a store of value, creating an insensitivity in the correlation dynamics these two more industrial metals and silver.

Papadamou and Markopoulos (2014) look at volatility transmission between currency exchange rates and gold and silver prices using hourly data between January 2010 and March 2012. A BEKK-GARCH model points towards volatility transmission from gold, the EUR/USD exchange rate and the GBP/USD exchange rate to silver but note vice versa.

Antonakakis and Kizys (2015) looks at volatility spillovers useing weekly data between 1987 and 2014 and using a generalised VAR framework and a Forecast Error Variance Decomposition (FEVD). On average silver returns contributes $52.78 \%$ of the FEVD to the other variables and receives an average of $50.90 \%$ from other variables. Platinum contributes $52.39 \%$ to the FEVD of other variables and receives an average of $49.61 \%$. In contrast to the two, palladium is found to be a net receiver of return spillovers. A similar picture is observed for volatility, where silver and platinum are net transmitters, while palladium is a net receiver of volatility spillovers. Even though the Global Financial crisis of 2008 weakened the role of silver returns as a net transmitter of shocks, it strengthened the role of platinum as a net 
transmitter of return shocks.

Using monthly futures closing prices for gold, silver, platinum and palladium traded on the New York Mercantile Exchange between 1984 and 2012 some of Batten et al. (2015)'s results contrast with Antonakakis and Kizys (2015). Silver is found to be a net transmitter of return spillovers, contributing $52 \%$ to gold returns, while platinum and palladium receive $49 \%$. But here silver proves to be a net receiver of volatility spillovers, it contributes only $29 \%$ to the volatility of the other three metals and receives $31 \%$. A time-varying approach shows that the Global Financial Crisis of 2008 increased the importance of silver as a net recipient of spillovers - somewhat in line with Antonakakis and Kizys (2015) who observe a weakening transmission of shocks for silver during that time. Conflicting results to those of Antonakakis and Kizys (2015) are also observed for platinum, which is neither a net transmitter nor a net receiver of return spillovers, but is a net receiver of volatility spillovers. Palladium is net receiver of both.

Kang et al. (2017) examine volatility spillover effects on six commodity futures, including silver. Results obtained from weekly silver futures prices between 2002 and 2016 indicate that equicorrelation between commodity futures increased during the recent Global Financial Crisis, and remained high during periods of economic and financial turmoil. Again silver was a net information transmitter to other commodity futures markets.

Bosch and Pradkhan (2015) take a different approach to volatility and examines if the position of speculators can be used to predict returns and return volatility of precious metal futures. The authors work with futures contracts traded on the COMEX between the $13^{\text {th }}$ of June 2006 and the $31^{\text {st }}$ of December 2013 and use a Brunetti and Buyuksahin (2009) rolling procedure to create a continuous series. The data of trading positions is obtained from Disaggregated Commitments of Traders (DCOT) and COT reports, similar to Mutafoglu et al. (2012) who also work with Commitments of Traders reports. The relationship between the variables is detected 
through a Johansen $(1991,1995)$ and an Engle and Granger (1987) test followed by a Vector Error Correction Model (VECM) and a VAR Model to detect short-term impacts. Results point towards a herding behaviour of traders on the silver market between October 2007 and December 2013 and on the platinum and palladium market between the entire estimation period from June 2006 to December 2013. Furthermore, evidence point towards a trend-following behaviour of non-commercial traders, a finding in line with Mutafoglu et al. (2012).

Sarwar (2016) identifies the interaction between the VIX, and the volatility on US Treasury notes, gold and silver markets. Implied futures market volatility examined using data from August 2007 to March 2009 is chosen to reflect the equity market crisis period. Results indicate a Granger relationship between increases in stock market volatility and increases in silver prices, implying that the impulse for investors to rebalance their portfolio towards silver begins with increases in the VIX.

Charlot and Marimoutou (2014) use daily data betweeen January 2005 and October 2012 in order to examine the volatility and correlation amongst WTI oil, gold, silver, platinum, the Euro/US Dollar exchange rate and the S\&P 500. The decision tree results from a Markov Switching model indicate that the volatility of silver responds strongly to economic shocks and is linked to specific events such as the Financial Crisis of 2008, while the response of platinum is very slow.

Luo and Ye (2015) looks at predictability potential of the Shanghai silver futures market using the CBOE Silver ETF Volatility Index (VXSLV). The authors take into account 139,500 observations between 2012 and 2014 and differentiate between realised volatility and implied volatility. Realised volatility is defined as the root of the sum of squared returns using a sampling frequency of 25 minutes. Previous literature showed that option-implied volatility contains information on future volatility, Luo and Ye (2015) believe this information can be found in options on the iShares silver trust 
fund. Trading volume, open interest and a momentum variable are added in the empirical model and the results show that the VXSLV has significant power in predicting daily and weekly volatility forecasts. Furthermore, adding trading volume, open interest and momentum leads to a significant improvement in forecasting the volatility of the Shanghai silver futures market.

Lyócsa and Molnár (2016) propose identifying one-day forward volatilities of gold and silver. High frequency data from January 2008 to December 2014 reveals that gold is more volatile than silver and that forecasts are less accurate in times of high market volatility. More interestingly, the GHAR type models provided above average forecasts, pointing towards the inferiority of univariate models in predicting the volatility of silver prices.

\section{The Macroeconomic Determinants of White Precious Metal Prices}

Precious metals have long been seen as a natural inflation hedge, as their production is limited by nature - in contrast to fiat currencies. Taylor (1998) uses data from 1914 to 1996 to assess the inflation hedging ability of white precious metals. The results for silver indicate that it was a long-run hedge over the period observed, but that it also served as a short-run hedge against the US CPI over many subperiods of the sample. A noteworthy finding is that silver was a hedge during the second Organisation of Oil Exporting Countries (OPEC) crisis of 1979, but not during the first OPEC crisis of 1973. For platinum and palladium, Johansen cointegration results indicate that the two white precious metals served as a long-run inflation hedge, while evidence also points towards the short-run hedging abilities of platinum.

Over a shorter period (1967-1999) looking only at after gold prices began to float more freely Adrangi et al. (2003) continues the investigation into the relationship between silver and US inflation. They use the Ameri- 
can Industrial Production Index (IP) as well as the Consumer Price Index. this paper's first framework predicts that a rising inflation rate will lead to a reduction of both economic activity and the demand for money. The authors argue that this would on the one hand lead to a reduction of industrial demand for silver, but might lead to an increase of the investment demand side due to silver's alleged ability to act as a hedge during inflationary times. The second framework is build upon the portfolio equilibrium model of Feldstein (1980). The framework is based on the assumption that the demand for gold and bonds in a portfolio is a function of expected real after-tax returns of the two assets. However, Feldstein et al. (1977) showed that the after-tax return on gold is higher than the after-tax return of bonds as long as the capital gains tax is lower than the ordinary income tax rate; therefore, during inflationary periods, the relative price of gold rises, making it a good inflation hedge. Using cointegration and causality tests, silver is shown to be a good hedge against inflation over the time period observed. Second, the Fischer (1930) hypothesis holds, in other words: real silver returns are not adversely affected by inflation. However results do no offer support in favour of the first hypothesis. A positive relationship between silver and the CPI in the long-run and the short-run is observed.

Radetzki (1989) looked at the factors that influenced the price of silver and platinum in the medium and long term. The analysis is done by differentiating between driving forces of supply and driving forces of demand between 1972 and 1987. Mine production across countries is found to be a more important factor of supply for silver than gold, which has a very large stock relative to other commodities. On the demand side, industrial demand dominates for silver; such as photographic, electrical, and also the jewellery industry. These findings lead Radetzki (1989) to conclude that two factors drive the price of silver: demand from industry and private inventories. Oil prices and official inventories are not believed to be amongst the major driving forces of the silver price, even though they are seen here as 
important in determining the price of gold. On the supply side for platinum scrap supply is not found to be a driver, though it is for silver. Industrial demand for platinum is again important for platinum prices, driven by its use in the automobile sector.

Bampinas and Panagiotidis (2015) uses a 220 year data set of annual silver and consumer prices in the United Kingdom and the United States of America to 2010 to look at the relationship in a time varying framework. Expected CPI series is derived from a Hodrick and Prescott (1997) filter and an asymmetric Christiano and Fitzgerald (2003) band-pass filter. For both the UK and the US, silver is found to share no long-run relationship with inflation; however, in a time-varying framework, a strong long-run relationship does exist between silver and UK inflation. Since even a timevarying relationship fails to exist for the US no hedging relationship exists. In all cases the long run relationship is not found to be 1:1 which is a necessary condition for silver to be an inflation hedge.

In a multiple-factor Arbitrage Pricing Theory (APT) McCown and Zimmerman (2007) finds a growing importance for inflation in driving silver prices. A high correlation between the price of silver and expected inflation is found, making it a good indicator of the latter, though gold is seen to perform better at this role than silver.

The effect of macroeconomic news announcements is first addressed by Christie-David et al. (2000) using 15 Minutes intraday data between the January 1992 and December 1995 for silver futures. Results show that silver futures prices respond strongly to the announcement of capacity utilisation and the unemployment rates. Inflation has a weak effect (a finding in line with Frankel and Hardouvelis (1985), as does hourly wages, business inventories, and construction spending. Other announcements have no measurable effect in this sample.

In the same year, Roache and Rossi (2010) re-examine the effect of macroeconomic news announcements on the price of silver futures relying 
on daily data between January 1997 and December 2009 using a GARCH model. Similar to Christie-David et al. (2000), the set of macroeconomic variables under observation is quite extensive but only the German IFO survey and the US Dollar index, both lagged by one day, have an effect on the price of silver over the entire time period considered. More variables are found to be significant for platinum. Here, results point towards the FOMC interest rate decision, alongside the lagged value of changes in non-farm payrolls, existing home sales, the German IFO survey and the US Dollar index. Finally, palladium is found to be influenced by the following variables: the GPD, industrial production, the employment cost index, existing home sales, the German IFO survey and the US Dollar index.

Similar to the work from Christie-David et al. (2000), Elder et al. (2012) work with intraday data between January 2002 and December 2008 to analyse the impact of US macroeconomic news announcements on the return, volatility and trading volume of gold, silver and copper futures. Advance retail sales, changes in nonfarm payrolls, durable goods orders, business inventories, construction spending, and new home sales announcements have a statistically significant negative influence on silver futures prices; only trade balance announcements are positively associated with silver futures prices. These results are in contrast to the findings of Christie-David et al. (2000) who observe an importance for the announcements of capacity utilisation, the unemployment rate and the CPI, all of which are not found to be statistically significant in influencing the price of silver futures in the work of Elder et al. (2012); indicating time-variation in the importance of macroeconomic announcements on the price of silver.

Adrangi et al. (2015) consider the response of intraday gold, silver and copper futures prices traded on the COMEX between January 1999 and December 2008 to 18 macroeconomic variables believed to influence the behaviour of financial markets in the United States. The results are then divided into different categories: thirty-minute return responses, thirty-minute 
return responses taking into account the surprise element, standardised inventory holdings and return responses, and finally, local inventory clustering and return responses. Across all different categories, capacity utilisation and industrial production have a positive significant relationship with the price of silver, results somewhat in line with Christie-David et al. (2000), but contrary to Elder et al. (2012) who find no significant relationship between either capacity utilisation nor industrial production with silver futures prices.

Thorbecke and Zhang (2009) analyse the effect of monetary policy surprises on commodity prices including silver. Chan and Mountain (1988) found that interest rates were a driver of silver prices, but did not effect interest rates. Thorbecke and Zhang (2009) first use Romer and Romer (2000) hypothesis's that a federal funds rate increase might lead to an increase in inflation by revealing the Fed's private information about inflation. The second theory, by Gürkaynak et al. (2005) predicts that an increase of the federal funds rate leads to a decrease in long-term expected inflation. Thorbecke and Zhang (2009) consider the time period between 1974 and 1979 as well as between 1989 and 2006; the period between 1980 and 1989 is omitted because the Fed abandoned fund rate targeting in 1979. Regression results differ substantially for both time periods considered. Between 1974 and 1979, an increase in the federal funds rate led to an increase in the price of silver as a reaction to an increased demand in answer to anticipated inflation. Between 1989 and 2006 however, an increase in the federal funds rate led to a decrease in the price of silver in expectation of increasing short-term real term interest rates; a finding in line with Frankel (2008). Soytas et al. (2009) results show that Turkish interest rates Granger cause silver prices.

Focusing more on explaining the price volatility of gold, silver, platinum and palladium through macroeconomic determinants, Batten et al. (2010) work with monthly data between January 1986 and May 2006 and express the expected return of silver as a function of the information available at a previous time interval while estimating the conditional standard devia- 
tions with the methodology of Davidian and Carroll (1987). The following macroeconomic variables are considered in the analysis: the S\&P 500 and it's dividend yield, the World excluding US stock index and it's dividend yield, the difference in interest rate yields between a US 10 years bond and a US 3 months Treasury bill, US M2 money supply, US industrial production, US inflation, the US Dollar index, and finally, US consumer confidence. The authors argue that these variables contribute to the effects of the business cycle, monetary environment and financial market sentiment on asset returns. Results show that neither monetary nor financial market variables are significant for silver price volatility. Instead, the volatility from the other precious metals markets has an effect on silver price volatility. These findings are in line with Sensoy (2013) concluding that the same macroeconomic factors do not jointly influence the price series of the four main precious metals. Results for platinum indicate a significant effect of stock market volatility during a part of the sample period under observation, while the effect of macroeconomic variables seems much stronger on palladium. Here, it seems that the volatility of the S\&P 500 and its dividend yield significantly effect the volatility of palladium prices.

Apergis et al. (2014) look into the nature of spillovers between the prices of gold and silver, stock markets, and different macroeconomic variables of the G7 countries using monthly data between January 1981 and December 2010. The authors use the Zurich silver price in US Dollar per kilogram and consider a vast amount of variables reflecting industrial production, inflation, unemployment, exchange rates, commodity prices, interest rates, government debt, money supply, equity prices, market capitalisation, price/earnings ratios, and price to book ratios. Apergis et al. (2014) work with a Factor-Augmented Vector Autoregressive (FAVAR) approach which the argue is better suited then a standard VAR model when considering large amounts of variables. Results indicate that the price of silver responds negatively to positive shocks of industrial production and interest rates, fur- 
thermore, a higher inflation and unemployment rate have a negative impact on the price of silver. The authors explain this negative relationship with inflation by saying that a higher inflation rate deteriorates the macroeconomic environment while adding to macroeconomic uncertainty, hence turning investors away from precious metal markets. On the other hand, FAVAR test results indicate that both positive money supply shocks and positive stock market shocks lead to higher silver prices.

Fernandez (2017) focuses her research on gold, silver and Platinum-group elements, amongst which platinum and palladium, and derives the differences in macroeconomic determinants for annual prices between 1930 and 2014 and for monthly and weekly prices between July 1992 and July 2016. On a yearly basis, a relationship between white precious metals prices and both global production and US consumption is identified. On a monthly basis, a strong relationship is identified between white precious metals and US industrial production as well as US monetary supply; the effects of South African mine production are also revealed. Finally, a very strong relationship is identified between the prices of gold and silver on a weekly basis during bullish environments, while platinum and palladium have a strong relationship with silver during bearish periods. A very interesting finding is the rise in importance of the price of white precious metals and consumer confidence and exchange rates in the United States, in line with the rise in importance of white precious metals as an investments asset.

Ciner (2017) takes a very specific approach and predicts the price of silver, platinum and palladium by looking at the level of the South African Rand in relying on daily data between October 1996 and July 2016. Results indicate a unilateral effect from exchange rates to the price of white precious metals but not the other way around, while the effect is strongest on palladium, than platinum and finally silver, in that order. Indeed, the ability of exchange rates movements of the Rand to forecast palladium prices remains significant under different model specifications, which it doesn't for both 
platinum and silver.

\section{The White Precious Metals and Other Assets}

\subsection{Gold}

Gold and silver are seen as a pair, and therefore might be assumed to be close substitutes from the perspective of a financial economics. However using data between December 1979 and March 1981 Koutsoyiannis (1983) finds a very low value for the elasticity of the price of gold with respect to changes in the price of silver (0.08) suggesting the opposite is true. There are many possible reasons for this but one must be that the industrial uses of silver are far more numerous than gold.

Historically the ratio of gold and silver prices have been a long running feature of economic discussions, with many commentators focusing on their historical parity ratio of 16:1 from a monetary perspective. Ma (1985) tests if a trading strategy can be developed based on changes in a derived equilibrium parity ratio looking at daily spot gold and silver prices between 1974 and 1984. The technical trading rule developed does provide excess returns, but only before trading costs with trading being very frequent. Ma and Soenen (1988) extends this to futures prices and find that this is more profitable than spot trading, but again only before transaction costs.

Looking data between the December 1993 and December 1995, Adrangi et al. (2000) collect 15 minutes intraday data of silver futures. A bivariate GARCH model is used to examine the high frequency relationship between gold and silver futures. Results point towards a bicausal relationship between gold and silver returns where the silver contracts carry the burden for spread convergence - Adrangi et al. (2000) believe that this is due to a faster reaction of the gold market to macroeconomic factors. Also noteworthy are the strong volatility spillovers from the gold to the silver market.

In an attempt to understand the relationship between gold and silver prices, Chan and Mountain (1988) consider the price of gold and silver 
traded in Toronto and the Canadian bank rate using weekly basis between March 1980 and February 1983, testing for granger causality. Results point towards a causal relationship between the price of gold and the price of silver with lags of up to four weeks. Using daily cash and futures prices between January 1982 and July 1992 Wahab et al. (1994) also find a strong correlation between gold and silver spot and futures prices. The authors use this to propose a trading strategy which generates profits but with a very level high risk.

Escribano and Granger (1998) find a long-run relationship between gold and silver spot prices using monthly data from 1971 to 1990, which is especially strong during the silver price bubble which burst in March 1980. Finally, a linear regression indicates a strong simultaneous relationship between gold and silver returns across the entire time period considered. Using daily data between 1992 and 1998 Ciner (2001) uses Johansen Cointegration tests to confirm Escribano and Granger (1998)'s contention that this long run relationship started to break down in the 1990's. Based on his findings he advises market participants not to consider gold and silver as substitutes when hedging similar risks. Lucey and Tully (2006b) reviews the findings of Ciner (2001) using weekly COMEX prices between January 1978 and November 2002 and a dynamic cointegration analysis, involving estimations of Johansen cointegration tests over various time windows. A visual application of the Hansen and Johansen (1992) method (used before by Rangvid (2001) for example) shows that the stable relationship between gold and silver prevails over time. Concidering that results indicate no cointegration between gold and silver from 1992 to 1998, Lucey and Tully (2006b) concludes that the findings of Ciner (2001) might only be driven by the choice of the time period considered and should not be regarded as empirical sound. Gerolimetto et al. (2006) also finds a dynamic long run relationship between gold and silver.

Building upon the results of Escribano and Granger (1998), Baur and 
Tran (2014) enlarge the sample considered and look at monthly gold and silver prices between January 1970 and July 2011 in order to analyse their potential long-run relationship. Closely following the method proposed by Escribano and Granger (1998), results show that the price of gold drives the price of silver and therefore the long-run relationship. Time-variation is observed in the relationship, namely the disconnection of gold and silver prices in the 1990s.

Considering monthly data from 1970 to 2015, Pierdzioch et al. (2015) work with a Residual Augmented Least Squares (RALS) test for noncointegration, looking at the problem from another angle. Even though gold and silver are cointegrated during major parts of the whole sample, evidence for noncointegration is found in the mid 1990s and the early 2000s as in the earlier papers.

Zhu et al. (2016) take a quantile regression approach to the relationship between gold and silver by considering weekly data from 1968 to 2016 . A Quantile Autoregressive Distributed Lag model based on the Johansen procedure detects a positive long-run relationship between gold and silver that is mainly driven by the tail quantiles outside the interquantile range. Further results indicate that prices of silver are more susceptible to contemporaneous price changes of gold, though this adjustment is stronger when silver prices are in their extremes.

Liu and Chou (2003) employ a general method of fractional cointegration analysis to study the gold-silver spread in both cash and futures markets. Results indicate slow-adjustment long-memory processes and that the futures and cash spreads between gold and silver are cointegrated. Further results point towards the ability of futures spreads to reflect information before cash spreads. Batten et al. (2013) consider daily gold and silver futures prices between January 1999 and December 2005 to look at spread returns. They detect long-term dependence by using statistical techniques proposed by Hurst $(1951,1956)$. Results indicate a dominant positive dependence 
between the spread returns, even though negative dependence is also observed during some of the sample. An important result for investors is the proposed trading strategy derived from Hurst coefficients which indicates when to buy or sell. This outperforms both a simple buy-and-hold strategy and a moving-average strategy.Auer (2016) augments to include transaction costs. Auer (2016)'s trading strategy continues to out preform on a buy and hold bass even after transaction costs.

Kearney and Lombra (2009) is one of the few to focus on the relationship between gold and platinum prices between 1985 and 2006 focusing on the short-term shifts from positive to negative correlation. Results obtained from the hedge books of 93 gold mining companies between 1996 and 2006 uncover that forward sales are negatively related to gold prices and equilibrium errors and therefore altered the return on gold and explain the shift towards a negative relationship with platinum prices.

Morales and Andreosso-O'Callaghan (2011)'s results from a GARCH model point towards a significantly positive relationship between precious metal returns, where the prices of gold, silver,platinum and palladium tend to appreciate simultaneously and also depreciate at the same time.

Hammoudeh et al. (2010) look at conditional volatility, correlation dependency and interdependency for all four major precious metals and the US Dollar/Euro exchange rate using daily spot prices between 1999 and 2007. Results point towards high conditional correlation between gold and silver. Results for platinum and palladium indicate a high correlation amongst the return of the two white precious metals, but to a very low correlation between gold and palladium. Interestingly, the authors point towards superior portfolio diversification benefits of platinum in comparison to silver, hence advising investors to hold more platinum than silver.

Chng and Foster (2012) argue that while gold is demanded by investors as a safe haven, but that during good economic times firms stockpile silver, platinum and palladium for industrial consumption. Using daily data be- 
tween 1996 and 2010, they test whether or not the implied convenience yield of precious metals affect returns, volatility and volume dynamics of other precious metals. The authors derive time series for the implied convenience yield of a precious metal taking into account the percentage storage costs of the metal (a $0.43 \%$ annual fee). A VAR model augmented with a subsample analysis point towards significant cross-metal interactions amongst convenience yields of precious metals, though gold and silver seem to be more influential depending on the state of the economy. Silver is more convenient to hold during positive economic times since it carries the heaviest industrial usage. Regarding the relationship between gold and silver, it seems that a long-run equilibrium relation is only observed during normal economic times. Further findings point towards the greater influence of the convenience yields of gold and silver in comparison to that of platinum and palladium.

Kucher and McCoskey (2016) consider weekly data for gold, silver and platinum prices between 1975 and 2015 in order to understand their long-run relationship. Results indicate a cointegration relationship between gold and silver prices as well as gold and platinum prices, though these relationships are time-varying: they tend to decline around business cycle peaks and increase during recessions. Finally, while Kucher and McCoskey (2016) finds that the prices of precious metals are influenced by the actual economic condition, the long-run relationship amongst them seems to be unaffected by short term macroeconomic shocks.

\subsection{Other Assets}

Soytas et al. (2009) examine both short-run and long-run information transmission between the Brent oil price, the Turkish interest rate, the Turkish Lira/US Dollar exchange rate, and finally, the domestic spot price of gold and silver considering daily data between March 2003 and of March 2007. Short-run dynamics are identified using generalised impulse responses in a VAR model,in order to make the ordering of the variables irrelevant. There 
is evidence for unidirectional causality from gold to silver in the long-run. Concerning oil, evidence shows that price shocks have a negative impact on the price of silver, pointing to silvers' industrial importance in Turkey. On the other hand, the silver spot price quoted on the Istanbul Gold Exchange (IGE) is found to have a significant positive impact on the Brent oil price in the short-run.

A few years later, Bhar and Hammoudeh (2011) take a more global approach and look at the relationship between WTI oil, copper, gold, silver, short-run US interest rates, a trade-weighted average index of the value of the US dollar, and finally, the MSCI world equity index. Bhar and Hammoudeh (2011) fit weekly data between January 1990 and May 2006 into a regime-dependent VAR model. Results relying on different model specifications show no evidence for a significant relationship between oil prices and silver. However, a positive relationship between silver and the US Dollar exchange rate is observed, indicating that silver can't be considered a hedge against a depreciating dollar.

Jain and Ghosh (2013) conduct an analysis similar to that of Soytas et al. (2009) focusing on India by looking at cointegration relationships and Granger causality between daily prices of Brent oil, gold, silver, platinum, and the Indian Rupee/US Dollar exchange rate between January 2009 and December 2011. Evidence points towards a strong relationship between gold and silver - also in explaining each others error variances. Granger causality is observed between oil and and silver, implying that the silver price has predictive powers for international oil prices. Results also uncover a bidirectional causality between gold and platinum, indicating that platinum starts to behave like an alternative investment to gold. Finally $9.55 \%$ of the variance of oil is found to explain the variance of platinum.

Charlot and Marimoutou (2014) results indicate a low correlation between oil and silver (0.41) that increased since 2009 and a high correlation between silver and platinum/gold (0.74 and 0.83 respectively). An increase 
in correlation since the Global Financial Crisis is also observed between oil and platinum (0.44), while a strong correlation also exists between platinum and gold (0.72).

Focusing more on the effect that Brent oil price shocks have on the volatility of precious metal prices, Behmiri and Manera (2015) consider daily spot prices of aluminum, copper, lead, nickel, tin, zinc, gold, silver, platinum and palladium between July 1993 and January 2014. Outliers in the GARCH model are detected via the Doornik and Ooms (2005, 2008) procedure inspired by Chen and Liu (1993) allowing to distinguish between outliers affecting the levels of the series and outliers affecting future conditional variances (a discussion on the different types of outliers and their effects on GARCH models can be found in Sakata and White (1998) and in Hotta and Tsay (2012). This approach provides Behmiri and Manera (2015) with two sets of data: the original time series and a data set corrected for outliers. Finally, the Mork (1989) method developed for oil prices is used to differentiate between positive and negative shocks. Empirical results indicate that negative oil price shocks do not affect the volatility of silver, while positive oil price shocks decrease the volatility of silver prices. Regarding platinum, it is found that negative oil price shocks increase the volatility of platinum while positive oil price shocks decrease the volatility of platinum prices. the volatility of palladium prices is always increased, disregarding the type of oil price shock. However, considering the data set corrected for outliers, only the positive oil price shocks remain significant in affecting silver price volatility. Behmiri and Manera (2015) give two possible reasons for the fact that negative oil price shocks become insignificant when the series are corrected for outliers: first, detected outliers in the silver market are due to shocks in the oil market, and second, the volatility of both the silver and the oil price are likely to be affected by the same events.

Similar to Jain and Ghosh (2013), the paper by Bildirici and Türkmen (2015a) analyses cointegration and causality relationship between oil, gold, 
silver and copper using monthly data between January 1973 and November 2012. The oil price considered is the equally weighted average of the spot price of Brent, Dubai and West Texas Intermediate (WTI) oil. A Brock et al. (1996) test indicates nonlinearity in the series, hence leading Bildirici and Türkmen (2015a) to perform a nonlinear ARDL test of cointegration: an asymmetric extension of the linear ARDL approach proposed by Pesaran et al. (2001) (examples of nonlinear ARDL tests and their applications can be found in Katrakilidis and Trachanas (2012) and Bildirici and Türkmen (2015b). Regarding causality amongst the variables, Bildirici and Türkmen (2015a) argue that a standard linear Granger approach might not be appropriate due to the nonlinear nature of the series. The authors therefore propose to work with a Hiemstra and Jones (1994) modified Baek and Brock (1992) test to reveal information about the positive and negative nature of shocks, and a Kyrtsou and Labys (2006) test to detect response asymmetry from one variable to another. Results indicate a positive long-run relationship between oil and silver, where a $1 \%$ increase in the price of oil results in a $1.33 \%$ increase in the price of silver. However, the different causality tests indicate conflicting results about the relationship between oil and silver; Bildirici and Türkmen (2015a) therefore advice the reader to be cautious when interpreting these results.

Reboredo and Ugolini (2016) examine the impact of strong bidirectional oil price movements on ten metal prices, including silver, platinum and palladium, using weekly spot prices between January 2000 and October 2015. Results point towards an asymmetric effect of oil price spillovers, where the effects of upward price movements were larger than those of downwards price movements. Reboredo and Ugolini (2016) also take a specific look at the Global Financial Crisis and find that it did not affect the spillover effects running from oil to the three white precious metals, evidence that the relationship between oil and silver, platinum and palladium is not time-varying. 


\section{Silver Futures and Forwards}

Garbade and Silber (1983) studies the extent to which hedgers use futures contracts to manage silver price risk. Building upon the assumption that the futures price for a commodity should be equal to the cash price plus a premium reflecting the deferred payment on the futures contract Garbade and Silber (1983) develop a pricing model that is able to assess whether or not futures contracts are good substitutes for a cash market position and detect in which market price changes first appear. Results for silver indicate that the elasticity of supply is quite high, the authors argue that this is due to the low storage costs for silver and the ability to sell short silver very easily. Another interesting finding indicates that in contrary to gold, where the spot price depends largely on the futures price, price discovery for silver is more evenly distributed amongst the spot and the futures price.

Ntungo and Boyd (1998) consider weekly silver futures and try to understand whether or not neural network models Kaastra and Boyd (1995) outperform traditional ARIMA models in predicting silver prices. Neural network procedures were designed based on the structure of the brain and consists of a collection of input units and processing units receiving the data. In contrary to other forecasting procedures, neural networks compare the results of their analysis with the desired output, adding a machine learning element to the procedure Hecht-Nielsen (1990). While the predictive models generated positive returns, neural network results for silver indicate that the more complex models did not perform better than the traditional ARIMA model considered; an explanation provided by the authors is that the data considered might not have been highly nonlinear.

Longin (1999) derives optimal margin levels required in silver futures contracts in the light that it should be high enough to protect brokers against insolvent customers, but also low enough to minimise the additional costs for investors. They work with observations derived from the COMEX between 1975 and 1994. Results for long investors show that optimal margins 
are smaller than the historically observed margin requirements for a probability of margin violation above $10 \%$, a similar observation is found for short investors where the optimal margin requirement is smaller than the historically observed margin requirements for a probability of margin violation above $25 \%$.

Another paper that looks at margin levels of silver futures is that of Chatrath et al. (2001a) using daily data between 1986 and 1995. Market volatility is measured firslty based on the dispersion of prices, while the second method is based on a GARCH model. The costs imposed by futures margins are estimated with a Two Stage Least Square (2SLS) model and differentiates between different types of traders. Empirical results for silver futures reveal that open interest and trading volume are relatively insensitive to margin changes far away from the maturity date - indicating they are seen as a transcation cost and not an opportunity-cost. Also results show that small traders and speculators are more sensitive to margin changes than hedgers and spreaders.

Cifarelli and Paladino (2015) focuses on hedgers and speculators to analyse the behaviour of futures returns of silver with daily data between January 1990 and January 2010. Using a non-linear CCC-GARCH to model the reactions of hedgers and speculators to volatility shifts in the silver futures markets and a two-state Markov-switching procedure they find that individual periods of high futures return volatility are associated to specific intensified trading activities from hedgers or speculators respectively. Results indicate that the effect of hedgers on the silver futures market is far more important than the effect of speculation activities, while the behaviour of speculators is very much dependent on the level of volatility in the silver futures market.

Looking at the silver futures market in the United States and Japan, Xu and Fung (2005) analyse daily gold, silver and platinum futures data between November 1994 and March 2001 to detect across-market information 
flow amongst the contracts through a bivariate asymmetric ARMA-GARCH model. Intraday information transmission is measured with a Seemingly Unrelated Regression (SUR) framework. Results show that price transmission is strong between the markets and originates in the USA. Furthermore, SUR results point towards the speed at which new information is incorporated in the market - usually not longer than a day. Aruga and Managi (2011) also look at the US and the Japanese silver futures market. Johansen test results indicate that the daily prices considered between January 2001 and June 2010 are cointegrated while a causality test indicates that American prices are dominant in driving the cointegration relationship. Furthermore, results indicate that the Law of One Price (LOP) did not hold over the entire period, hence allowing investors to realise profits through arbitrage.

Paschke and Prokopczuk (2012) consider daily data of crude oil, copper, gold and silver between January 2006 and the June 2008 in order to understand whether or not continuous time pricing models can be used to reveal mispriced commodity futures prices. A set of different models reveals that excess returns can be realised based on the pricing errors present in the silver futures market - the evidence for gold is much weaker, which the authors blame on the much bigger size of the gold market.

\section{Exchange Traded Products and White Precious Metals}

The iShares silver trust fund mentioned earlier is part of the study of different other papers looking at the performance of silver Exchange Traded Funds (ETFs). Naylor et al. (2011) look at daily returns of three silver ETFs traded on the NYSE between May 2006 and December 2009 to understand whether or not abnormal returns could have been realised through these securities. The methodology is based upon a CAPM and a Classic Linear Regression Model (CLRM). Building the CAPM, the market under consideration is the S\&P 500 and the risk-free rate is given as the US 90 day

Treasury bill rate. Results show that the behaviour of silver ETFs is very 
similar to that of physical silver returns, particularly, the price movements do not follow a random walk. An important conclusion for investors is that using a filter trading rule Fama and Blume (1966), Solt and Swanson (1981), abnormal returns can be generated through ETFs, hence outperforming a passive investor.

ETFs also raise questions about how price discovery, which is traditionally seen as originating from futures markets, evolves in precious metals markets. Ivanov (2013) looks at this issue by examining at the relationship between silver ETFs, future prices and spot prices using 1 minute intradaily data between the $1^{\text {st }}$ of March 2009 and the $31^{\text {st }}$ of August 2009 using Hasbrook information shares. Silver ETFs largely dominate the information share against spot and futures prices with a value above $89 \%$; indicating that the price discovery role may be being overtaken by ETFs.

A few years later, Naylor et al. (2014) investigate the microstructure of silver investment funds and look more closely at tracking ability, tracking deviation, and the impact of market panics on ETF dynamics. Daily share prices, trading volumes and assets under management of two similar ETFs starting from April 2006 and July 2009 are used, with data up to December 2011. Following Frino and Gallagher (2001), results point towards an average daily tracking error of 112 basis points for silver ETFs which is maximised in times of high market volatility.

Similar to Luo and Ye (2015) who look at the iShares Silver Trust, but looking more specifically at market contagion during the 2010 Flash Crash, MacKenzie and Lucey (2013) use 4,695 one minute intraday observations between April 2010 and May 2010. Results point towards the vulnerability of the iShares Silver Trust to contagion.

Lau et al. (2017) opens the ETF investigation to platinum and palladium and considers daily ETF prices for gold, silver, platinum, palladium, oil and global equity between the $19^{\text {th }}$ of June 2006 and the $18^{\text {th }}$ of June 2016. An EGARCH procedure is used in order to ensure that the conditional variance is 
strictly positive and augmented with a frequency dynamics of connectedness procedure and a hidden semi-Markov model to measure the dynamics and intensity of return spillovers as well as to analyse the return characteristics of white precious metals. Results identify a strong relationship between gold and silver ETFs, but a relatively unimportant relationship between oil and white precious metals ETFs, where oil price movements spill over on silver and platinum but not on palladium. Regarding the relationship of white precious metal ETFs with the global equity ETF, results do point towards a cointegration relationship between equity and precious metals, but the effect of equity ETFs on white precious metals ETFs are relatively unimportant.

\section{Conclusion}

A primary finding from this review is the relatively small amount of research available on platinum and palladium when compared with silver, and the studies on gold reviewed by O'Connor et al. (2015). This in part reflects their more primary role as industrial metals but also possibly indicates that the benefits they could provide have not been fully addressed. Additionally the research to date has focused on investment in terms of the prices of the metals, a gap remains for research on the drivers of physical demand, such as coins, and supply for the metals, such as scrap. Additionally the focus has generally been on the prices from the London and American markets but more can be done on the remaining markets whose importance is growing.

Another outcome is the clear finding that they do form a single asset class of three homogeneous and interchangeable metals. It has been shown that they have different relationships with other assets, such as oil, divergent abilities in hedging risk. Any further resreach cannot lump the three together without an appreciation of their differences. 


\section{Bibliography}

Adrangi, B., Chatrath, A., and Christie-David, R. A. (2000). Price discovery in strategically-linked markets: the case of the gold-silver spread. Applied Financial Economics, 10(January):227-234.

Adrangi, B., Chatrath, A., Christie-David, R. A., Miao, H., and Ramchander, S. (2015). Stock-Versus-Flow Distinctions, Information, and the Role of Inventory. Journal of Futures Markets, 35(11):1003-1025.

Adrangi, B., Chatrath, A., and Raffiee, K. (2003). Economic Activity, Inflation, and Hedging: The Case of Gold and Silver Investments. The Journal of Wealth Management, 6(2):60-77.

Aggarwal, R. and Sundararaghavan, P. (1987). Efficiency of the silver futures market - An Empirical Study Using Daily Data. Journal of Banking and Finance, 11(1):49-64.

Agyei-Ampomah, S., Gounopoulos, D., and Mazouz, K. (2014). Does gold offer a better protection against losses in sovereign debt bonds than other metals? Journal of Banking \& Finance, 40(1):507-521.

Almudhaf, F. and AlKulaib, Y. (2016). Market timing in precious metals is detrimental to value creation. Applied Economics Letters, pages 1-6.

Andrews, D. W. (1993). Tests for Parameter Instability and Structural Change With Unknown Change Point. Econometrica, 61(4):821-856.

Antonakakis, N. and Kizys, R. (2015). Dynamic spillovers between commodity and currency markets. International Review of Financial Analysis, 41:303-319.

Apergis, N., Christou, C., and Payne, J. E. (2014). Precious metal markets, stock markets and the macroeconomic environment: a FAVAR model approach. Applied Financial Economics, 24(10):691-703. 
Arouri, M. E. H., Hammoudeh, S. M., Lahiani, A., and Nguyen, D. K. (2012). Long memory and structural breaks in modeling the return and volatility dynamics of precious metals. Quarterly Review of Economics and Finance, 52(2):207-218.

Aruga, K. and Managi, S. (2011). Tests on price linkage between the U.S. and Japanese gold and silver futures markets. Economics Bulletin, 31(2):1038-1046.

Auer, B. R. (2015). Superstitious seasonality in precious metals markets? Evidence from GARCH models with time-varying skewness and kurtosis. Applied Economics, 47(27):2844-2859.

Auer, B. R. (2016). On the performance of simple trading rules derived from the fractal dynamics of gold and silver price fluctuations. Finance Research Letters, 16:255-267.

Averbury, L. (1903). A short history of coins and currency. John Murray, London, 2nd edition.

Baek, E. and Brock, W. A. (1992). A general test for nonlinear Granger causality: Bivariate model. Working Paper.

Balcilar, M., Hammoudeh, S. M., and Asaba, N.-A. F. (2015). A regimedependent assessment of the information transmission dynamics between oil prices, precious metal prices and exchange rates. International Review of Economics \&3 Finance, 40:72-89.

Bampinas, G. and Panagiotidis, T. (2015). Are gold and silver a hedge against inflation? A two century perspective. International Review of Financial Analysis, 41:267-276.

Barnhill, T. M. and Powell, J. A. (1981). Silver Price Volatility: A Perspective on the July 1979 - April 1980 Period. Journal of Futures Markets, $1(4): 619-647$. 
Batten, J. A., Ciner, C., and Lucey, B. M. (2010). The macroeconomic determinants of volatility in precious metals markets. Resources Policy, $35(2): 65-71$.

Batten, J. A., Ciner, C., and Lucey, B. M. (2015). Which precious metals spill over on which, when and why? Some evidence. Applied Economics Letters, 22(6):466-473.

Batten, J. A., Ciner, C., Lucey, B. M., and Szilagyi, P. G. (2013). The structure of gold and silver spread returns. Quantitative Finance, 13(4):561570 .

Batten, J. A., Lucey, B. M., and Peat, M. (2016). Gold and silver manipulation: What can be empirically verified? Economic Modelling, 56:168-176.

Baur, D. G. (2013). The Autumn Effect of Gold. Research in International Business and Finance, 27(1):1-11.

Baur, D. G. and Tran, D. T. (2014). The long-run relationship of gold and silver and the influence of bubbles and financial crises. Empirical Economics, pages 1-17.

Behmiri, N. B. and Manera, M. (2015). The role of outliers and oil price shocks on volatility of metal prices. Resources Policy, 46(2):139-150.

Belousova, J. and Dorfleitner, G. (2012). On the diversification benefits of commodities from the perspective of euro investors. Journal of Banking \& Finance, 36(9):2455-2472.

Bhar, R. and Hammoudeh, S. M. (2011). Commodities and financial variables: Analyzing relationships in a changing regime environment. International Review of Economics and Finance, 20(4):469-484.

Bildirici, M. E. and Türkmen, C. (2015a). Nonlinear causality between oil and precious metals. Resources Policy, 46(2):202-211. 
Bildirici, M. E. and Türkmen, C. (2015b). The Chaotic Relationship between Oil Return, Gold, Silver and Copper Returns in TURKEY: Non-Linear ARDL and Augmented Non-linear Granger Causality. Procedia - Social and Behavioral Sciences, 210:397-407.

Bosch, D. and Pradkhan, E. (2015). The impact of speculation on precious metals futures markets. Resources Policy, 44:118-134.

Bredin, D., Conlon, T., and Potì, V. (2017). The price of shelter - Downside risk reduction with precious metals. International Review of Financial Analysis, 49:48-58.

Brock, W. A., Scheinkman, J. A., Dechert, W. D., and LeBaron, B. (1996). A test for independence based on the correlation dimension. Econometric Reviews, 15(3):197-235.

Brunetti, C. and Buyuksahin, B. (2009). Is Speculation Destabilizing? Available on SSRN.

Bruno, S. and Chincarini, L. (2010). A historical examination of optimal real return portfolios for non-US investors. Review of Financial Economics, 19(4):161-178.

Bry, G. and Boschan, C. (1971). Programmed Selection Of Cyclical Turning Points. In Cyclical Analysis of Time Series: Selected Procedures and Computer Programs, pages 7-63. The National Bureau of Economic Research, New York.

Bühlmann, P. and Hothorn, T. (2007). Boosting Algorithms: Regularization, Prediction and Model Fitting. Statistical Science, 22(4):477-505.

Bunnag, T. (2015). The precious metals volatility comovements and spillovers, hedging strategies in COMEX market. Journal of Applied Economic Sciences, 10(1):83-103. 
Caporin, M., Ranaldo, A., and Velo, G. G. (2015). Precious metals under the microscope: a high-frequency analysis. Quantitative Finance, 15(5):743759 .

Chan, M. W. L. and Mountain, D. C. (1988). The Interactive and Causal Relationships Involving Precious Metal Price Movements: An Analysis of the Gold and Silver Markets. Journal of Business 8 Economic Statistics, $6(1): 69-77$.

Chang, E. C., Chen, C., and Chen, S.-n. (1990). Risk and Return in Copper, Platinum, and Silver Futures. Journal of Futures Markets, 10(1):29-39.

Charles, A., Darné, O., and Kim, J. H. (2015). Will precious metals shine? A market efficiency perspective. International Review of Financial Analysis, 41:284-291.

Charlot, P. and Marimoutou, V. (2014). On the relationship between the prices of oil and the precious metals: Revisiting with a multivariate regime-switching decision tree. Energy Economics, 44:456-467.

Chatrath, A., Adrangi, B., and Allender, M. (2001a). The impact of margins in futures markets: Evidence from the gold and silver markets. Quarterly Review of Economics and Finance, 41(2):279-294.

Chatrath, A., Adrangi, B., and Shank, T. (2001b). Nonlinear Dependence in Gold and Silver Futures: Is It Chaos? The American Economist, $45(2): 25-32$.

Chen, C. and Liu, L.-M. (1993). Joint estimation of model parameters and outlier effects in time series. Journal of the American Statistical Association, 88(421):284-297.

Chen, M.-H. (2010). Understanding world metals prices-Returns, volatility and diversification. Resources Policy, 35(3):127-140. 
Cheng, W. H. and Hung, J. C. (2011). Skewness and leptokurtosis in GARCH-typed VaR estimation of petroleum and metal asset returns. Journal of Empirical Finance, 18(1):160-173.

Chng, M. T. and Foster, G. M. (2012). The Implied Convenience Yield of Precious Metals: Safe Haven versus Industrial Usage. Review of Futures Markets, 20(4):349-94.

Choi, K. and Hammoudeh, S. M. (2010). Volatility behavior of oil, industrial commodity and stock markets in a regime-switching environment. Energy Policy, 38(8):4388-4399.

Christiano, L. J. and Fitzgerald, T. J. (2003). The Band Pass Filter. International Economic Review, 44(2):435-465.

Christie-David, R. A., Chaudhry, M., and Koch, T. W. (2000). Do macroeconomics news releases affect gold and silver prices? Journal of Economics and Business, 52(5):405-421.

Cifarelli, G. and Paladino, G. (2015). A dynamic model of hedging and speculation in the commodity futures markets. Journal of Financial Markets, $25: 1-15$.

Ciner, C. (2001). On the long run relationship between gold and silver prices: A note. Global Finance Journal, 12(2):299-303.

Ciner, C. (2017). Predicting White Metal Prices by a Commodity Sensitive Exchange Rate. International Review of Financial Analysis, Forthcomin:1-24.

Ciner, C., Gurdgiev, C., and Lucey, B. M. (2013). Hedges and safe havens: An examination of stocks, bonds, gold, oil and exchange rates. International Review of Financial Analysis, 29:202-211. 
Cochran, S. J., Mansur, I., and Odusami, B. (2012). Volatility persistence in metal returns: A FIGARCH approach. Journal of Economics and Business, 64(4):287-305.

Cochran, S. J., Mansur, I., and Odusami, B. (2016). Conditional higher order moments in metal asset returns. Quantitative Finance, 16(1):151167.

Conover, C. M., Jensen, G. R., Johnson, R. R., and Mercer, J. M. (2008). Sector Rotation and Monetary Conditions. Journal of Investing, 17(1):3446.

Conover, C. M., Jensen, G. R., Johnson, R. R., and Mercer, J. M. (2009). Can Precious Metals Make Your Portfolio Shine? The Journal of Investing, 18(1):75-86.

Davidian, M. and Carroll, R. J. (1987). Variance Function Estimation. Journal of the American Statistical Association, 82(400):1079-1091.

Degiannakis, S. and Potamia, A. (2016). Multiple-days-ahead value-at-risk and expected shortfall forecasting for stock indices, commodities and exchange rates: Inter-day versus intra-day data. International Review of Financial Analysis, 49:176-190.

Demiralay, S. and Ulusoy, V. (2014). Non-linear volatility dynamics and risk management of precious metals. North American Journal of Economics and Finance, 30:183-202.

Dichev, I. D. and Janes, T. D. (2003). Lunar cycle effects in stock returns. Journal of Private Equity, 6(8):8-29.

Doornik, J. A. and Ooms, M. (2005). Outlier Detection in GARCH Models. Discussion Paper, 92(4):1-26.

Doornik, J. A. and Ooms, M. (2008). Multimodality in GARCH regression models. International Journal of Forecasting, 24(3):432-448. 
Elder, J., Miao, H., and Ramchander, S. (2012). Impact of macroeconomic news on metal futures. Journal of Banking \& Finance, 36(1):51-65.

Elliott, G., Komunjer, I., and Timmermann, A. (2005). Estimation and Testing of Forecast Rationality under Flexible Loss. Review of Economic Studies, 72(4):1107-1125.

Engle, R. F. (1984). Wald, likelihood ratio, and Lagrange multiplier tests in econometrics. In Handbook of Econometrics, volume II, pages 775-826.

Engle, R. F. and Granger, C. W. (1987). Co-Integration and Error Correction: Representation, Estimation, and Testing. Econometrica, 55(2):251276 .

Erb, C. B. and Harvey, C. R. (2006). The Strategic and Tactical Value of Commodity Futures. Financial Analysts Journal, 62(2):69-97.

Escribano, A. and Granger, C. W. (1998). Investigating the relationship between gold and silver prices. Journal of Forecasting, 17(2):81-107.

Fama, E. F. and Blume, M. E. (1966). Filter Rules and Stock-Market Trading. The Journal of Business, 39(1):226-241.

Fassas, A. P. (2012). Exchange-Traded Products investing and Precious Metal prices. Journal of Derivatives $\&$ Hedge Funds, 18(2):127-140.

Fay, S. (1982). The great silver bubble. Hodder and Stoughton.

Feldstein, M. (1980). Inflation, tax rules, and the prices of land and gold. Journal of Public Economics, 1(3):309-317.

Feldstein, M., Summers, L. H., and Wachter, M. (1977). Is the rate of Profit Falling? Brookings Papers on Economic Activity, 1977(1):211-228.

Fernandez, V. (2017). Some facts on the platinum-group elements. International Review of Financial Analysis, Forthcomin:1-38. 
Figuerola-Ferretti, I. and McCrorie, J. R. (2016). The shine of precious metals around the global financial crisis. Journal of Empirical Finance, $38(31935): 717-738$.

Fischer, I. (1930). The Theory of Interest: Chapter 1.

Frank, M. and Stengos, T. (1989). Measuring the Strangeness of Gold and Silver Rates of Return. The Review of Economic Studies, 56(4):553-567.

Frankel, J. A. (2008). The Effect of Monetary Policy on Real Commodity Prices. In Campbell, J. Y., editor, Asset Prices and Monetary Policy, chapter 7, pages 291-333. University of Chicago Press.

Frankel, J. A. and Hardouvelis, G. A. (1985). Commodity Prices, Money Surprises and Fed Credibility. Journal of Money, Credit and Banking, 17(4):425-438.

Frino, A. and Gallagher, D. R. (2001). Tracking S\&P 500 Index Funds. Journal of Portfolio Management, 28(1):44-55.

Fritsche, U., Pierdzioch, C., Rülke, J.-C., and Stadtmann, G. (2013). On the directional accuracy of survey forecasts: the case of gold and silver. Applied Economics Letters, 20(12):1127-1129.

Garbade, K. D. and Silber, W. L. (1983). Price Movements and Price Discovery in Futures and Cash Markets. Review of Economics 8 Statistics, $65(2): 289$.

Gerolimetto, M., Procidano, I., and Luchini, S. (2006). Dynamic cointegration and Relevant Vector Machine: the relationship between gold and silver. Society for Computational Economics working paper series, 380:25 .

Gil-Alana, L. A., Aye, G. C., and Gupta, R. (2015a). Trends and cycles in historical gold and silver prices. Journal of International Money and Finance, 58:98-109. 
Gil-Alana, L. A., Chang, S., Balcilar, M., Aye, G. C., and Gupta, R. (2015b). Persistence of precious metal prices: A fractional integration approach with structural breaks. Resources Policy, 44:57-64.

Gold Field Mineral Services Ltd. (2015). GFMS Platinum \& Palladium survey 2015.

Goss, B. A. (1983). Forward pricing and efficiency in the silver market. Resources Policy, 9(1):54-63.

Gürkaynak, R. S., Sack, B., and Swanson, E. (2005). The Sensitivity of Long-Term Interest Rates to Economic News: Evidence and Implications for Macroeconomic Models. American Economic Review, 95(1):425-436.

Hammoudeh, S. M., Araújo Santos, P., and Al-Hassan, A. (2013). Downside risk management and VaR-based optimal portfolios for precious metals, oil and stocks. The North American Journal of Economics and Finance, $25: 318-334$.

Hammoudeh, S. M. and Yuan, Y. (2008). Metal volatility in presence of oil and interest rate shocks. Energy Economics, 30(2):606-620.

Hammoudeh, S. M., Yuan, Y., McAleer, M., and Thompson, M. A. (2010). Precious metals-exchange rate volatility transmissions and hedging strategies. International Review of Economics and Finance, 19(4):633-647.

Hansen, H. and Johansen, S. (1992). Recursive Estimation in Cointegrated VAR Models.

Hecht-Nielsen, R. (1990). Neurocomputing. Addison-Wesley Publishing Company.

Hiemstra, C. and Jones, J. D. (1994). Testing for Linear and Nonlinear Granger Causality in the Stock Price- Volume Relation. The Journal of Finance, 49(5):1639-1664. 
Hillier, D., Draper, P., and Faff, R. W. (2006). Do Precious Metals Shine? An Investment Perspective. Financial Analysts Journal, 62(2):98-106.

Hodrick, R. J. and Prescott, E. C. (1997). Postwar US business cycles: an empirical investigation. Journal of Money, Credit and Banking, pages $1-16$.

Hotta, L. K. and Tsay, R. S. (2012). Outliers in GARCH Processes. In Bell, W. R., Tolan, S. H., and McElroy, T. S., editors, Economic time series: modeling and seasonality, pages 337-358. CRC Press.

Hurst, H. E. (1951). Long-Term Storage Capacity of Reservoirs. Transactions of the American Society of Civil Engineers, 116(1):770-799.

Hurst, H. E. (1956). The Problem of Long-Term Storage in Reservoirs. International Association of Scientific Hydrology. Bulletin, 1(3):13-27.

Ivanov, S. I. (2013). The influence of ETFs on the price discovery of gold, silver and oil. Journal of Economics and Finance, 37(3):453-462.

Jaffe, J. F. (1989). Gold and Gold Stocks as Investments for Institutional Portfolios. Financial Analysts Journal, 45(2):53-59.

Jain, A. and Ghosh, S. (2013). Dynamics of global oil prices, exchange rate and precious metal prices in India. Resources Policy, 38(1):88-93.

Johansen, S. (1991). Estimation and Hypothesis Testing of Cointegration Vectors in Gaussian Vector Autoregressive Models. Econometrica, 59(6):1551-1580.

Johansen, S. (1995). Likelihood-Based Inference in Cointegrated Vector Autoregressive Models. Oxford University Press, New York.

Kaastra, I. and Boyd, M. S. (1995). Forecasting Futures Trading Volume Using Neural Networks. Journal of Futures Markets, 15(8):953-970. 
Kang, S. H., McIver, R., and Yoon, S.-M. (2017). Dynamic spillover effects among crude oil, precious metal, and agricultural commodity futures markets. Energy Economics, 62:19-32.

Katrakilidis, C. and Trachanas, E. (2012). What drives housing price dynamics in Greece: New evidence from asymmetric ARDL cointegration. Economic Modelling, 29(4):1064-1069.

Kearney, A. A. and Lombra, R. E. (2009). Gold and platinum: Toward solving the price puzzle. Quarterly Review of Economics and Finance, 49(3):884-892.

Kocagil, A. E. and Topyan, K. (1997). An Empirical Note on Demand for Speculation and Futures Risk Premium: A Kalman Filter Application. Review of Financial Economics, 6(1):77-93.

Kolb, R. W. and Rodriguez, R. J. (1987). Friday the Thirteenth: "Part VII" - A Note. The Journal of Finance, 42(5):1385-1387.

Koutsoyiannis, A. (1983). A short-run pricing model for a speculative asset, tested with data from the gold bullion market. Applied Economics, 15(5):563-581.

Kucher, O. and McCoskey, S. (2016). The long-run relationship between precious metal prices and the business cycle. The Quarterly Review of Economics and Finance, (September):1-42.

Kyrtsou, C. and Labys, W. C. (2006). Evidence for chaotic dependence between US inflation and commodity prices. Journal of Macroeconomics, $28(1): 256-266$.

Lashgari, M. K. (1992). Information From Successive Changes in Gold and Silver Prices During Phases of the Business Cycles. Journal of Economics and Finance, 16(2):13-30. 
Lau, M. C. K., Vigne, S. A., Wang, S., and Yarovaya, L. (2017). Return Spillovers Between White Precious Metal ETFs: The Role of Oil, Gold, and Global Equity. International Review of Financial Analysis, Forthcomin:1-38.

Levene, H. (1960). Robust tests for equality of variances. In Contributions to Probability and Statistics: Essays in Honor of Harold Hotelling, pages 278-292. Stanford University Press.

Li, S. and Lucey, B. M. (2017). Reassessing the role of precious metals as safe havens - what colour is your haven and why? (february 8, 2017). available at ssrn: https://ssrn.com/abstract=2906707 or http://dx.doi.org/10.2139/ssrn.2906707.

Liu, S.-M. and Chou, C.-H. (2003). Parities and Spread Trading in Gold and Silver Markets: A Fractional Cointegration Analysis. Applied Financial Economics, 13(12):899-911.

Lo, A. W. (2004). The Adaptive Markets Hypothesis. The Journal of Portfolio Management, 30(5):15-29.

Lobato, I. N., Nankervis, J. C., and Savin, N. (2001). Testing for Autocorrelation Using a Modified Box-Pierce Q Test. International Economic Review, 42(1):187-205.

Longin, F. M. (1999). Optimal Margin Level in Futures Markets: Extreme Price Movements. Journal of Futures Markets, 19(2):127-152.

Lucey, B. M. (2010). Lunar seasonality in precious metal returns? Applied Economics Letters, 17(9):835-838.

Lucey, B. M. and Li, S. (2015). What precious metals act as safe havens, and when? Some US evidence. Applied Economics Letters, 22(1):35-45. 
Lucey, B. M. and Tully, E. (2006a). Seasonality, risk and return in daily COMEX gold and silver data 1982 - 2002. Applied Financial Economics, 16(4):319-333.

Lucey, B. M. and Tully, E. (2006b). The evolving relationship between gold and silver 1978-2002: evidence from a dynamic cointegration analysis: a note. Applied Financial Economics Letters, 2(1):47-53.

Lucey, M. E. and O'Connor, F. A. (2016). Mind the gap: Psychological barriers in gold and silver prices. Finance Research Letters, 17:135-140.

Luo, X. and Ye, Z. (2015). Predicting volatility of the Shanghai silver futures market: What is the role of the U.S. options market? Finance Research Letters, 15:68-77.

Lyócsa, Š. and Molnár, P. (2016). Volatility forecasting of strategically linked commodity ETFs: gold-silver. Quantitative Finance, 16(12):1809-1822.

Ma, C. K. (1985). Spreading between the Gold and Silver Markets: Is There a Parity? Journal of Futures Markets, 5(4):579-594.

Ma, C. K. and Soenen, L. A. (1988). Arbitrage Opportunities in Metal Futures Markets. The Journal of Futures Markets, 8(2):199-209.

MacKenzie, D. and Lucey, B. M. (2013). Correlation Behaviour of iShares Silver Trust during the 2010 Flash Crash. Available on SSRN.

McCown, J. R. and Zimmerman, J. R. (2007). Analysis of the Investment Potential and Inflation-Hedging Ability of Precious Metals. Meinders School of Business.

McDonald, D. and Hunt, L. B. (1982). A history of platinum and its allied metals. Johnson Matthey Plc.

Mensi, W., Hammoudeh, S. M., and Kang, S. H. (2015). Precious metals, cereal, oil and stock market linkages and portfolio risk management: Evidence from Saudi Arabia. Economic Modelling, 51(July 2008):340-358. 
Milonas, N. T. (1986). Price Variability and the Maturity Effect in Futures Markets. Journal of Futures Markets, 6(3):443-460.

Morales, L. and Andreosso-O'Callaghan, B. (2011). Comparative analysis on the effects of the Asian and global financial crises on precious metal markets. Research in International Business and Finance, 25(2):203-227.

Morales, L. and Andreosso-O'Callaghan, B. (2014). Volatility analysis of precious metals returns and oil returns: An ICSS approach. Journal of Economics and Finance, 38(3):492-517.

Mork, K. A. (1989). Oil and the Macroeconomy When Prices Go Up and Down: An Extension of Hamilton's Results. Journal of Political Economy, $97(3): 740-744$.

Mutafoglu, T. H., Tokat, E., and Tokat, H. A. (2012). Forecasting precious metal price movements using trader positions. Resources Policy, $37(3): 273-280$.

Nadarajah, S., Afuecheta, E., and Chan, S. (2015). GARCH modeling of five popular commodities. Empirical Economics, 48(4):1691-1712.

Narayan, P. K., Narayan, S., and Sharma, S. S. (2013). An analysis of commodity markets: What gain for investors? Journal of Banking $\mathcal{G}$ Finance, 37(10):3878-3889.

Naylor, M. J., Wongchoti, U., and Gianotti, C. (2011). Abnormal Returns in Gold and Silver Exchange Traded Funds. The Journal of Index Investing, $2(2)$.

Naylor, M. J., Wongchoti, U., and Ith, H. (2014). Market Microstructure of Precious Metal ETFs. The Journal of Index Investing, 5(2):48-56.

Nowman, K. B. and Wang, H. (2001). Modelling commodity prices using continuous time models. Applied Economics Letters, 8(5):341-345. 
Ntungo, C. and Boyd, M. (1998). Commodity Futures Trading Performance Using Neural Network Models versus ARIMA Models. The Journal of Futures Markets, 18(8):965-983.

O'Connor, F. A., Lucey, B. M., Batten, J. A., and Baur, D. G. (2015). The financial economics of gold - A survey. International Review of Financial Analysis, 41:186-205.

Papadamou, S. and Markopoulos, T. (2014). Investigating Intraday Interdependence Between Gold, Silver and Three Major Currencies: The Euro, British Pound and Japanese Yen. International Advances in Economic Research, 20(4):399-410.

Paschke, R. and Prokopczuk, M. (2012). Investing in commodity futures markets: can pricing models help? The European Journal of Finance, 18(1):59-87.

Pesaran, M. H., Shin, Y., and Smith, R. J. (2001). Bounds testing approaches to the analysis of level relationships. Journal of Applied Econometrics, 16(3):289-326.

Pesaran, M. H. and Timmermann, A. G. (1992). A Simple Nonparametric Test of Predictive Performance. Journal of Business \& Economic Statistics, 10(4):461-465.

Pesaran, M. H. and Timmermann, A. G. (1994). A generalization of the nonparametric Henriksson-Merton test of market timing. Economics Letters, $44(1-2): 1-7$.

Phillips, P. C., Shi, S., and Yu, J. (2015). Testing for Multiple Bubbles: Historical Episodes of Exuberance and Collapse in the S\&P 500. International Economic Review, 56(4):1043-1078.

Pierdzioch, C., Risse, M., and Rohloff, S. (2015). Cointegration of the 
prices of gold and silver: RALS-based evidence. Finance Research Letters, $15: 133-137$.

Pierdzioch, C., Risse, M., and Rohloff, S. (2016a). A boosting approach to forecasting gold and silver returns: economic and statistical forecast evaluation. Applied Economics Letters, 23(5):347-352.

Pierdzioch, C., Risse, M., and Rohloff, S. (2016b). Are precious metals a hedge against exchange-rate movements? An empirical exploration using bayesian additive regression trees. North American Journal of Economics and Finance, 38:27-38.

Pierdzioch, C., Rülke, J.-C., and Stadtmann, G. (2013). A note on forecasting the prices of gold and silver: Asymmetric loss and forecast rationality. Quarterly Review of Economics and Finance, 53(3):294-301.

Radetzki, M. (1989). Precious metals - The fundamental determinants of their price behaviour. Resources Policy, 15(3):194-208.

Rangvid, J. (2001). Increasing convergence among European stock markets? A recursive common stochastic trends analysis. Economics Letters, 71(3):383-389.

Reboredo, J. C. and Uddin, G. S. (2016). Do financial stress and policy uncertainty have an impact on the energy and metals markets? A quantile regression approach. International Review of Economics and Finance, 43:284-298.

Reboredo, J. C. and Ugolini, A. (2016). The impact of downward/upward oil price movements on metal prices. Resources Policy, 49:129-141.

Roache, S. K. and Rossi, M. (2010). The effects of economic news on commodity prices. Quarterly Review of Economics and Finance, 50(3):377385. 
Roberts, M. C. (2009). Duration and characteristics of metal price cycles. Resources Policy, 34(3):87-102.

Romer, C. D. and Romer, D. H. (2000). Federal Reserve Information and the Behavior of Interest Rates. The American Economic Review, 90(3):429457.

Sakata, S. and White, H. (1998). High Breakdown Point Conditional Dispersion Estimation with Application to S\&P500 Daily Returns Volatility. Econometrica, 66(3):529-567.

Sarafrazi, S., Hammoudeh, S. M., and Araújo Santos, P. (2014). Downside risk, portfolio diversification and the financial crisis in the eurozone. Journal of International Financial Markets, Institutions and Money, 32(1):368-396.

Sari, R., Hammoudeh, S. M., and Soytas, U. (2010). Dynamics of oil price, precious metal prices, and exchange rate. Energy Economics, 32(2):351362.

Sarwar, G. (2016). Examining the flight-to-safety with the implied volatilities. Finance Research Letters, 20:118-124.

Sensoy, A. (2013). Dynamic relationship between precious metals. Resources Policy, 38(4):504-511.

Sharpe, W. F. and Tint, L. G. (1990). Liabilities-A new approach. Journal of Portfolio Management, 16(2):5-10.

Solt, M. E. and Swanson, P. J. (1981). On the Efficiency of the Markets for Gold and Silver. The Journal of Business, 54(3):453-478.

Soytas, U., Sari, R., Hammoudeh, S. M., and Hacihasanoglu, E. (2009). World oil prices, precious metal prices and macroeconomy in Turkey. Energy Policy, 37(12):5557-5566. 
Taylor, N. J. (1998). Precious metals and inflation. Applied Financial Economics, 8(2):201-210.

The Silver Institute (2016). World Silver Survey 2016.

Thorbecke, W. and Zhang, H. (2009). Monetary Policy Surprises and Interest Rates: Choosing between the Inflation-Revelation and Excess Sensitivity Hypotheses. Southern Economic Journal, 75(4):1114-1122.

Urquhart, A. (2016). How predictable are precious metal returns ? European Journal of Finance, To Appear(0):1-24.

Varela, O. (1999). Futures and realized cash or settle prices for gold, silver, and copper. Review of Financial Economics, 8:121-138.

Vivian, A. and Wohar, M. E. (2012). Commodity volatility breaks. Journal of International Financial Markets, Institutions and Money, 22(2):395422.

Wahab, M., Cohn, R. A., and Lashgari, M. K. (1994). The Gold-Silver Spread: Integration, Cointegration, Predictability, and Ex-Ante Arbitrage. The Journal of Futures Markets, 14(6):709-756.

White, H. (1980). A Heteroskedasticity-Consistent Covariance Matrix Estimator and a Direct Test for Heteroskedasticity. Econometrica, 48(4):817838 .

Woodward, W. A., Cheng, Q., and Gray, H. (1998). A k-Factor GARMA Long-Memory Model. Journal of Time Series Analysis, 19(4):485-504.

Xu, X. E. and Fung, H. G. (2005). Cross-market linkages between U.S. and Japanese precious metals futures trading. Journal of International Financial Markets, Institutions and Money, 15:107-124.

Yang, S.-R. and Brorsen, B. W. (1993). Nonlinear Dynamics of Daily Futures Prices: Conditional Heteroskedasticity or Chaos? Journal of Futures Markets, 13(2):175-191. 
Yuan, K., Zheng, L., and Zhu, Q. (2006). Are investors moonstruck? Lunar phases and stock returns. Journal of Empirical Finance, 13(1):1-23.

Zhang, Z. and Zhang, H.-K. (2016). The dynamics of precious metal markets VaR: A GARCHEVT approach. Journal of Commodity Markets, 4(1):1427.

Zhu, H., Peng, C., and You, W. (2016). Quantile behaviour of cointegration between silver and gold prices. Finance Research Letters, 19:119-125. 